\title{
Granite microporosity changes due to fracturing and alteration: secondary mineral phases as proxies for porosity and permeability estimation
}

\author{
Martin Staněk ${ }^{1}$ and Yves Géraud ${ }^{2}$ \\ ${ }^{1}$ Institute of Geophysics, Czech Academy of Sciences, Prague, 14131, Czech Republic \\ ${ }^{2}$ GeoRessources Laboratory, University of Lorraine, Nancy, 54500, France
}

Correspondence: Martin Staněk (stanekm@ig.cas.cz)

Received: 4 October 2018 - Discussion started: 30 October 2018

Revised: 18 December 2018 - Accepted: 10 January 2019 - Published: 4 February 2019

\begin{abstract}
Several alteration facies of fractured Lipnice granite are studied in detail on borehole samples by means of mercury intrusion porosimetry, polarized and fluorescent light microscopy, and microprobe chemical analyses. The goal is to describe the granite void space geometry in the vicinity of fractures with alteration halos and to link specific geometries with simply detectable parameters to facilitate quick estimation of porosity and permeability based on, for example, drill cuttings. The core of the study is the results of porosity and throat size distribution analyses on 21 specimens representing unique combinations of fracture-related structures within six different alteration facies basically differing in secondary phyllosilicate chemistry and porosity structure. Based on a simple model to calculate permeability from the measured porosities and throat size distributions, the difference in permeability between the fresh granite and the most fractured and altered granite is 5 orders of magnitude. Our observations suggest that the porosity, the size of connections and the proportion of crack porosity increase with fracture density, while precipitation of iron-rich infills as well as of finegrained secondary phyllosilicates acts in the opposite way. Different styles and intensities of such end-member agents shape the final void space geometry and imply various combinations of storage, transport and retardation capacity for specific structures. This study also shows the possibility to use standard mercury intrusion porosimetry with advanced experimental settings and data treatment to distinguish important differences in void space geometry within a span of a few percent of porosity.
\end{abstract}

\section{Introduction}

The void space in granitic rocks is localized in faults, fractures and adjacent damage zones characterized by elevated microfracture density (Kranz, 1983; Scholz et al., 1993; Vermilye and Scholz, 1999; Zang et al., 2000; Bertrand et al., 2018) or in volumes altered by metamorphic, hydrothermal and weathering processes (Jamtveit et al., 2008, 2009, 2011; Wyns et al., 2015; Walter et al., 2018). Both fracturing and alteration modify the granite void space geometry and thus affect its physical properties including porosity, permeability, thermal conductivity and retardation capacity (Benson et al., 2006; Brace et al., 1968; Géraud, 1994; Rosener and Géraud, 2007; Schild et al., 2001; Yoshida et al., 2009; Zoback and Byerlee, 1975). Understanding the impact of these processes on granite is important for safe and sustainable management of geothermal projects (Géraud et al., 2010; Moeck, 2014), drinking water resources (Banfield and Eggleton, 1990; Lachassagne et al., 2011) and hydrocarbon reservoirs (Gutmanis, 2009; Trice, 2014) as well as of disposal of hazardous waste (Hooper, 2010; Rempe, 2007). Microstructural evolution during the different kinds of strain affecting the granite is linked to porosity modifications and permeability variations. The objectives of this paper are in the first step to define these links and in the second step to develop a chart linking the different chemical compositions of the phyllosilicate phases and the reservoir properties (porosity and permeability).

Brittle fracturing is associated with formation of low aspect voids (fractures sensu lato) enhancing permeability even at low porosities mainly dependent on the degree of intercon- 
nection within the fracture network (Long and Witherspoon, 1985). On the contrary, further mechanical disintegration by fault wear processes produces fine-grained gouge and therefore low threshold size and connectivity impeding permeability (Géraud et al., 1995, 2006; Bense et al., 2013). Fracturing may be accompanied or succeeded by fracture wall dissolution or precipitation due to chemically active fluids within the fracture network (Boyce et al., 2003; Ferry, 1979; Mazurier et al., 2016; Nishimoto and Yoshida, 2010), which may either increase or decrease the porosity and threshold size (Géraud et al., 2010; Katsube and Kamineni, 1983; Yoshida et al., 2009). Also, volumetric expansion related to alteration of primary sheeted silicates such as biotite may induce local stress variations producing fractures (Lachassagne et al., 2011). Conceptual models of porosity and permeability distribution in complex fracture or fault zones have been drawn to account for a variety of conductive and sealing structures (Bense et al., 2013; Caine et al., 1996; Evans et al., 1997; Faulkner et al., 2010, 2011; Mitchell and Faulkner, 2009; Wilson et al., 2003). Porosity-permeability relations of these structures are not straightforward since permeability depends on the pore-throat arrangement and scales linearly with the porosity and by power law with the characteristic threshold size (Bernabé et al., 2003; David et al., 1994; Katz and Thompson, 1987; Wardlaw et al., 1987).

In order to better understand the impact of the abovementioned processes on the void space geometry of a low porosity granitic rock, we investigated the structure, composition and porosity parameters of drill core samples representing various fracture and alteration settings of the late Variscan Lipnice granite (Bohemian Massif, central Europe). We have (1) characterized the optical and chemical properties of principal alteration phases by polarized light and electron analytical microscopy, (2) imaged representative void space structures by fluorescent light microscopy of epoxy-saturated thin sections and (3) quantified in detail the related variations in connected total and free porosity and pore throat size distribution by mercury injection tests.

\section{Tested granite}

\subsection{Geological setting of the Lipnice granite}

We collected samples of a $150 \mathrm{~m}$ deep drill core $(4.5 \mathrm{~cm}$ in diameter) of the MEL-5 borehole (located at lat 49.620716, long 15.410324) previously drilled in the Lipnice granite within the Melechov pluton (MP), Czech Republic, that has been chosen by the Czech Radioactive Waste Repository Authority (RAWRA) as a research training site. The MP represents the northernmost outcropping part of the NE segment of the Moldanubian batholith, which belongs to the deeply eroded high grade orogenic root of the eastern part of the European Variscan orogen, the Moldanubian Zone, within the Bohemian Massif (Fig. 1a). This segment of the
Moldanubian batholith is chiefly made up of late-orogenic "Eisgarn" granites emplaced at 330-300 Ma (Bankwitz et al., 2004; Breiter and Sulovský, 2005; Gerdes et al., 2003; Schulmann et al., 2008; Verner et al., 2014; Žák et al., 2011, 2014) and is hosted by cordierite-bearing migmatites and migmatized paragneisses recording peak metamorphic conditions 670-750 ${ }^{\circ} \mathrm{C}$ and $0.5 \mathrm{GPa}$ at the contact with the MP (Schulmann et al., 1998). The MP has an elliptical map outline of $10 \mathrm{~km} \times 14 \mathrm{~km}$, reaches to a depth of $6-15 \mathrm{~km}$ (Šrámek et al., 1996; Trubač et al., 2014) and outcrops as four peraluminous two-mica granites disposed in a concentric manner (Fig. 1b). The granites have similar chemical and modal compositions with higher $\mathrm{SiO}_{2}$ content, lower modal proportion of biotite and higher grain size towards the pluton center (Harlov et al., 2008; Matějka and Janoušek, 1998). The sampled Lipnice granite is the external, southeasterly offcenter unit intimately associated with the host rock by gradual granite-migmatite contacts, frequent paragneiss enclaves or strongly anisotropic structure marked by biotite schlieren in the granite (Staněk et al., 2013) and frequent melt pockets or granite dikes in the host rock. The average grain size of the Lipnice granite is $0.7 \mathrm{~mm}$ and its modal content is $33 \%-35 \%$ quartz, $29 \%-33 \%$ plagioclase, $17 \%-22 \% \mathrm{~K}-$ feldspar, $6 \%-9 \%$ muscovite and 5\%-9\% biotite (Procházka and Matějka, 2004; Staněk et al., 2013). Accessory minerals include ilmenite, zircon, monazite, sillimanite and fluorapatite (Harlov et al., 2008; Procházka and Matějka, 2004).

The fracture system of the MP consists of 5 fracture sets (Lexa and Schulmann, 2006; Staněk, 2013) also recognized within the borehole (Fig. 1c and d). The most regularly developed fractures at the scale of the pluton belong to two steep and mutually orthogonal sets (sets 1 and 2) of joints related to postmagmatic cooling-induced shrinkage. Fractures of set 1 strike WNW-ESE, their size ranges from meters to tens of meters and their spacing is on the order of meters. Fractures of set 2 strike NNE-SSW, terminate on fractures of set 1 and their size and spacing are approximately 1 order of magnitude lower than for set 1 . In quarries and on outcrops within a kilometer from the studied borehole the set 2 fractures appear in clusters spaced by one to several tens of meters, with each cluster containing fractures with spacing on the order of centimeters to decimeters. Commonly for set 2 and set 4 fractures, a detailed analysis of the fracture distribution within the MEL-5 borehole (Lexa and Schulmann, 2006) shows a bimodal distribution of spacing with one peak on the order of millimeters to centimeters and the other on the order of meters to tens of meters. The set 3 fractures are the least abundant in terrain and are represented by moderately to gently dipping conjugated fractures of approximately NW-SE strike, and size and spacing on the order of meters. The set 4 fractures terminate on fractures of sets 1 and 2 and are represented by steep, NNW-SSE to N-S striking faulted joints or faults with size, spacing and clustering similar to set 2 . The set 5 fractures are represented by subhorizontal to gently dipping sheeting joints with a size on the order of me- 

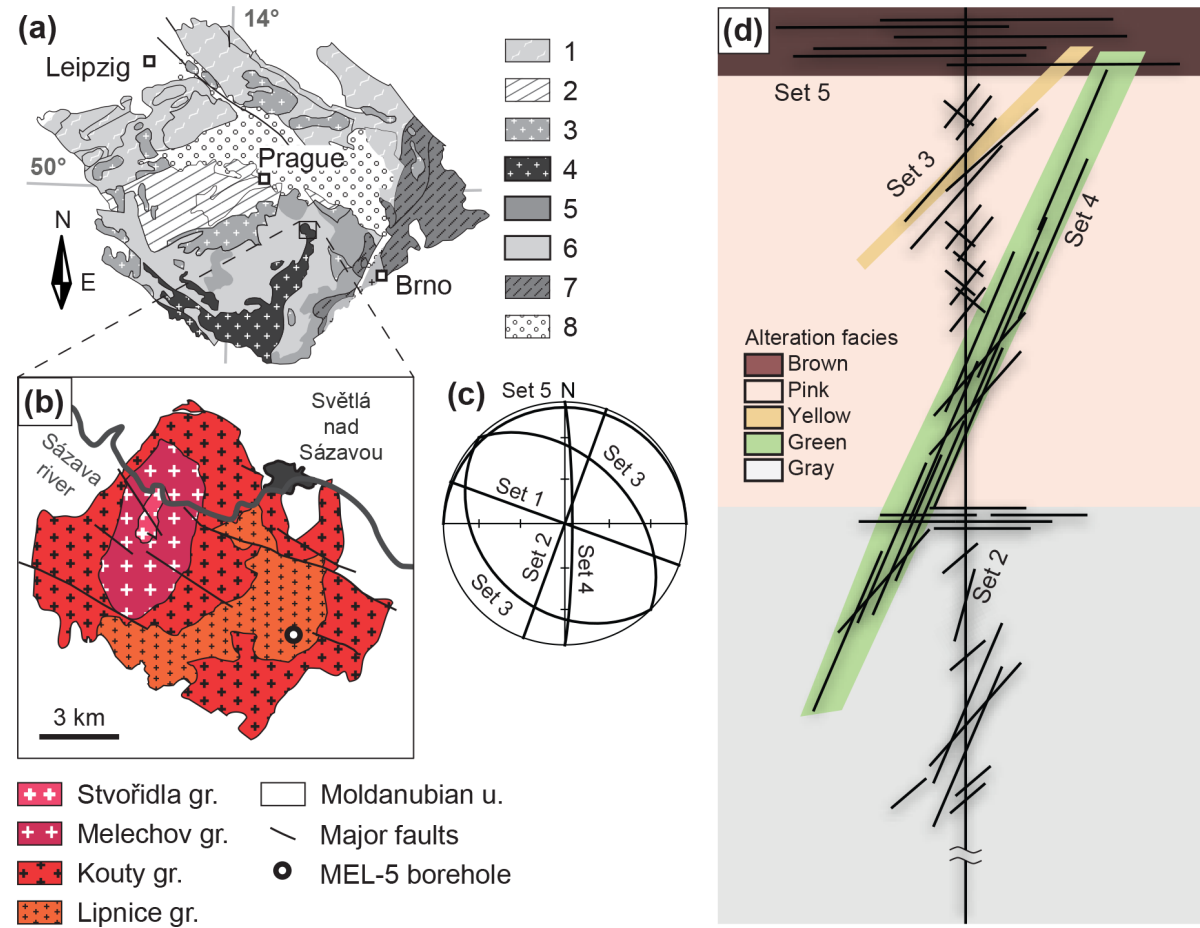

Figure 1. Maps showing the location of the sampled borehole. (a) Simplified geological map of the Bohemian Massif (modified after Franke 2000) 1: Saxothuringian and Lugian, 2: Teplá-Barrandian, 3: Variscan granitoids, 4: Moldanubian batholith, 5: Gföhl assemblage, 6: Drosendorf and Ostrong assemblage, 7: Brunovistulian, and 8: Cretaceous sedimentary cover; (b) geological map of the Melechov pluton (modified after Machek, 2011) with gr. representing granite and u. representing unit; (c) stereoplot (Schmidt projection) of the fracture sets recognized within the Melechov pluton based on Lexa and Schulmann (2006) and Staněk (2013); (d) interpretative schematic sketch of the fracture sets and their structural relationship with respect to the alteration facies distribution within the borehole.

ters and spacing progressively increasing with depth by 1 or 2 orders of magnitude over several tens of meters as observed on the deepest exposed quarry walls.

\subsection{Fracture and alteration setting of core samples}

The fracture density in the borehole was measured based on acoustic and optical borehole data and direct observation of the core (Lexa and Schulmann, 2006). At the scale of the borehole, the fracture density (FD) distribution varies between 0.2 and $12 \mathrm{~m}^{-1}$ and there is a complex zonation of the fracture-related alteration (Fig. 2). The majority of fractures is concentrated within the first $60 \mathrm{~m}$ below land surface (b.l.s.) corresponding to the vertical extent of densely spaced sheeting joints (Lexa and Schulmann, 2006). In this segment the FD is dominantly higher than $1 \mathrm{~m}^{-1}$, there are four fracture corridors with FD between 3 and $12 \mathrm{~m}^{-1}$ and most of the fractures are associated with pale pink to red alteration halos extending several centimeters to the fracture walls and with dark red to brown fracture infills dominantly less than $3 \mathrm{~mm}$ thick. In addition, three major fracture corridors $\left(\mathrm{FD}>5 \mathrm{~m}^{-1}\right)$ feature distinct colors of the granite matrix and fracture infills: pale brown matrix and dark brown infills $(0-5 \mathrm{~m}$ b.l.s. $)$, pale yellow matrix and green infills (21-23 m b.l.s.), and pale green matrix and green infills ( $42-57 \mathrm{~m}$ b.1.s.). In contrast, the lower segment of the borehole $(60-150 \mathrm{~m}$ b.l.s.) is characterized by FD dominantly lower than $1 \mathrm{~m}^{-1}$ and by two fracture corridors with FD between 3 and $4 \mathrm{~m}^{-1}$. Also, the alteration character is remarkably different: the granite near fractures has a gray color similar to the granite far from fractures and the fractures are dominantly barren.

We collected core pieces from 4 to $40 \mathrm{~cm}$ long representative of the macroscopically different fracture and alteration settings as follows (cf. Fig. 2). The gray granite with no fractures, hereafter referred to as "fresh granite", represented by sample 11 corresponds to the least fractured and altered granite within the sample collection. According to the acoustic and optical borehole images (Lexa and Schulmann, 2006) and direct observation of the core, the closest fracture was at a distance of $2 \mathrm{~m}$ from the sample. The gray granite distant several centimeters from fractures, hereafter referred to as "fractured granite", is represented by the fresh parts (beyond the pink alteration halos of fractures) of samples 3 and 5 . The gray granite adjacent to barren fractures, hereafter referred to as "weakly altered granite", is represented by sample 10. The pink granite occurring in the alteration halos of the majority of fractures in the upper part of the borehole (hereafter referred to as "pink granite") is represented by the 

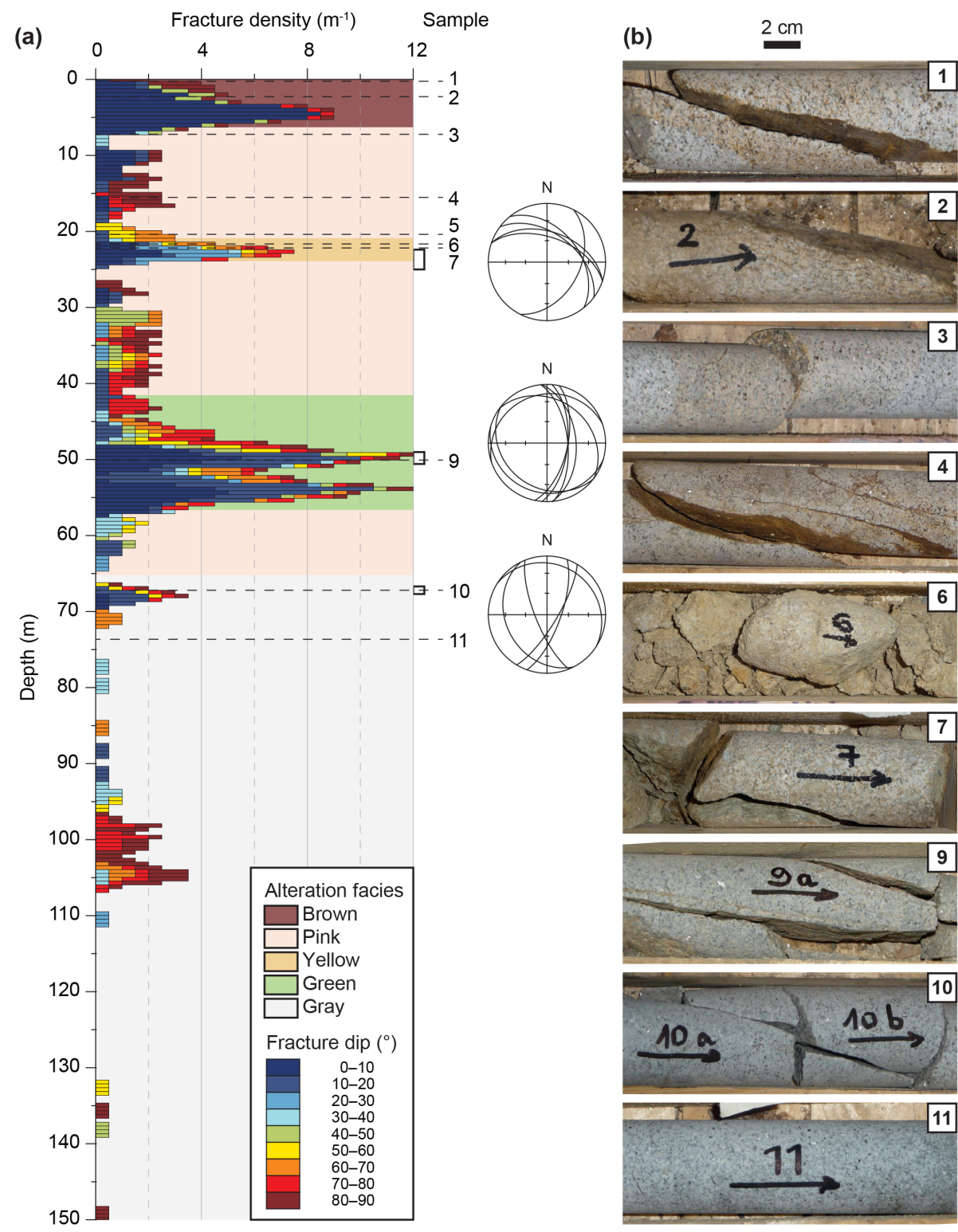

Figure 2. Fracture and alteration setting of samples. (a) Borehole log showing fracture density distribution (modified after Lexa and Schulmann, 2006), macroscopic alteration zones and position of samples. The pole diagrams (Schmidt projection) show orientation of fractures in the vicinity of samples with the depth range defined by the rectangles at the right side of the log (based on the acoustic borehole image, not available for the uppermost $22.5 \mathrm{~m}$ ); (b) photographs of the samples.

altered volume of samples 3, 4 and 5. In terms of fracturerelated structures, the latter samples represent a single fracture wall, a fracture corridor and a highly porous fracture infill, respectively. The pale green granite associated with the fracture corridor at $50 \mathrm{~m}$ b.l.s., hereafter referred to as "green granite", is represented by sample 9 . The pale yellow granite associated with the fracture corridor at $22 \mathrm{~m}$ b.l.s., hereafter referred to as "yellow granite", is represented by samples 7 and 6. The latter samples represent a fracture corridor and a fault gouge, respectively. The pale brown granite occurring in the uppermost part of the borehole (hereafter referred to as "brown granite") is represented by samples 1 and 2 collected near a single fracture and within a fracture corridor, respectively.

\section{Methodology}

\subsection{Thin sections for optical and electron microscope analyses}

For light and electron microscopy, we prepared thin sections $2.5 \mathrm{~cm} \times 3.5 \mathrm{~cm}$ in size from slab specimens vacuum- 
impregnated with epoxy resin containing fluorescent dye. For fracture-related samples, the sections were oriented perpendicular to the master fracture plane and immediately adjacent to or comprising the fracture surface(s).

Photographs of thin sections documenting the optical mineral properties and the connected microporosity distribution were acquired under polarized light (PL), cross-polarized light (XPL) and green fluorescent light (FL) using a petrographic microscope equipped with digital camera. To improve the contrast of the acquired FL images, only the green channel was used and converted to gray scale.

Point chemical composition analyses and elemental maps were acquired from the thin sections by an electron microprobe (Cameca SX100, GeoRessources laboratory, Nancy, France) using a focused electron beam of $1 \mu \mathrm{m}$ diameter with an accelerating voltage of $15 \mathrm{kV}$ and a beam current of $12 \mathrm{nA}$. The standards used for calibration of elements $\mathrm{Si}, \mathrm{Al}, \mathrm{Ti}, \mathrm{Cr}$, $\mathrm{Fe}, \mathrm{Mn}, \mathrm{Mg}, \mathrm{Ca}, \mathrm{Na}$ and $\mathrm{K}$ were albite ( $\mathrm{Si}, \mathrm{Na}$ ), corundum (Al), hematite $(\mathrm{Fe})$, forsterite $(\mathrm{Mg})$, pyrophanite (Ti, Mn), andradite $(\mathrm{Ca})$, orthoclase $(\mathrm{K})$ and $\mathrm{Cr}_{2} \mathrm{O}_{3}(\mathrm{Cr})$.

\subsection{Specimens for porosimetry}

From the core samples, we prepared $\sim 40$ specimens for mercury injection porosimetry (MIP) in order to account for specific fracturing and alteration features in different portions of the samples and we selected 21 of them for this paper in order to depict both the general trends and the variability of each facies (Fig. 3). One specimen represents the fresh granite (11) and one the non-altered fractured granite (3_1). Two specimens represent the weakly altered granite with one comprising the barren fracture surface (10_1), while from the other (10_2) a superficial layer (ca. $1 \mathrm{~mm}$ thick) of the fracture surface was ground off prior to the analysis. Three specimens represent the green granite: 9_7 represents the matrix with only a thin and dominantly sealed fracture contained within the specimen, 9_4 a clay-rich fracture surface and 9_1 a cohesive partially open fracture. Three specimens represent the yellow granite in a fracture corridor: 7_3 represents the matrix, 7_1 a clay-rich fracture surface and 7_10 a cohesive partially open fracture. One specimen represents the yellow granite fault gouge (specimen 6). Three specimens represent the pink granite near a single fracture: $3 \_2$ represents the matrix, 5_3 a macroscopically porous fracture surface and 5_5 a cohesive partially open fracture. Two specimens were prepared from the pink granite in a fracture corridor with one comprising macroscopically nonporous iron-oxide-rich fracture surface (4_1), while from the other (4_2) the iron-oxiderich material (less than $1 \mathrm{~mm}$ thick) was ground off prior to the analysis. Two specimens represent the brown granite near a single fracture: 1_2 represents the matrix and 1_1 a fracture surface with iron-oxide-rich material. Three specimens represent the brown granite in the fracture corridor: 2_2 represents the matrix with little macroscopic porosity, 2_3 the matrix with frequent macroscopic cavities and 2_1 a com- bination of a cohesive partially open fracture and a fracture surface with iron-oxide-rich material.

\subsection{Mercury injection porosimetry (MIP)}

MIP was used to measure the connected total and free porosity, the throat size distribution and the bulk density. The term "throat" reflects a simplified scheme of the rock pore space made up of large spaces referred to as pores, which are connected by smaller spaces or constrictions referred to as throats (Wardlaw et al., 1987). Since the MIP results represent the core of our study, it is appropriate to describe the fundaments and some detailed aspects of the experimental protocol. The MIP takes advantage of the fact that mercury is an electrically conductive nonwetting liquid with respect to many solids including common rocks. During the experiment, mercury is forced into the voids of airevacuated specimen by stepwise application of external pressure. At each pressure increment the increment of mercury volume intruded into the specimen is calculated from measured changes in electrical capacitance of the metal-coated stem of a penetrometer (specimen holder) due to the replacement of mercury by electrically nonconductive air or oil (Fig. 4a). The relation between the size of the access to the voids and the pressure applied on mercury is based on the Young-Laplace Eq. (1):

$D=\frac{-4 \gamma \cos \theta}{p}$,

where $D(\mathrm{~m})$ is the diameter of a pipe pore or the halfsize of the smaller dimension of a crack pore (Lenormand et al., 1983; Washburn, 1921), $\gamma$ is the mercury surface ten-

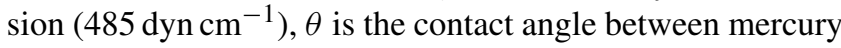
and solid $\left(130^{\circ}\right)$ and $p$ is the pressure $(\mathrm{Pa})$. Taking into account the minimum and maximum pressure enabled by the porosimeter (Micromeritics AutoPore IV), the resulting volume vs. throat-size curves cover a throat-size range from $300 \mu \mathrm{m}$ (which corresponds to the vacuum at the start of the experiment) down to $5 \mathrm{~nm}$ at the highest pressure. For easier visual interspecimen comparison of the throat size distributions we plotted the results by means of incremental curves calculated from the initial cumulative values.

It has been demonstrated that if large pores are accessible by small throats, the mercury forced into the pore remains in it after the mercury pressure is decreased to atmospheric pressure (Wardlaw and McKellar, 1981; Yu and Wardlaw, 1986a, b). To take advantage of this phenomenon called trapping, the MIP was executed in three phases (Fig. 4b): (I) intrusion - the pressure increases from vacuum to the maximum, (II) extrusion - the pressure decreases down to atmospheric and (III) reintrusion - it increases again to the maximum value. The volume of intruded mercury after the intrusion corresponds to the total connected porosity (stage $\mathrm{C}$ in Fig. 4c). The volume that remains in the specimen at ambient pressure at the end of the extrusion corresponds to the 

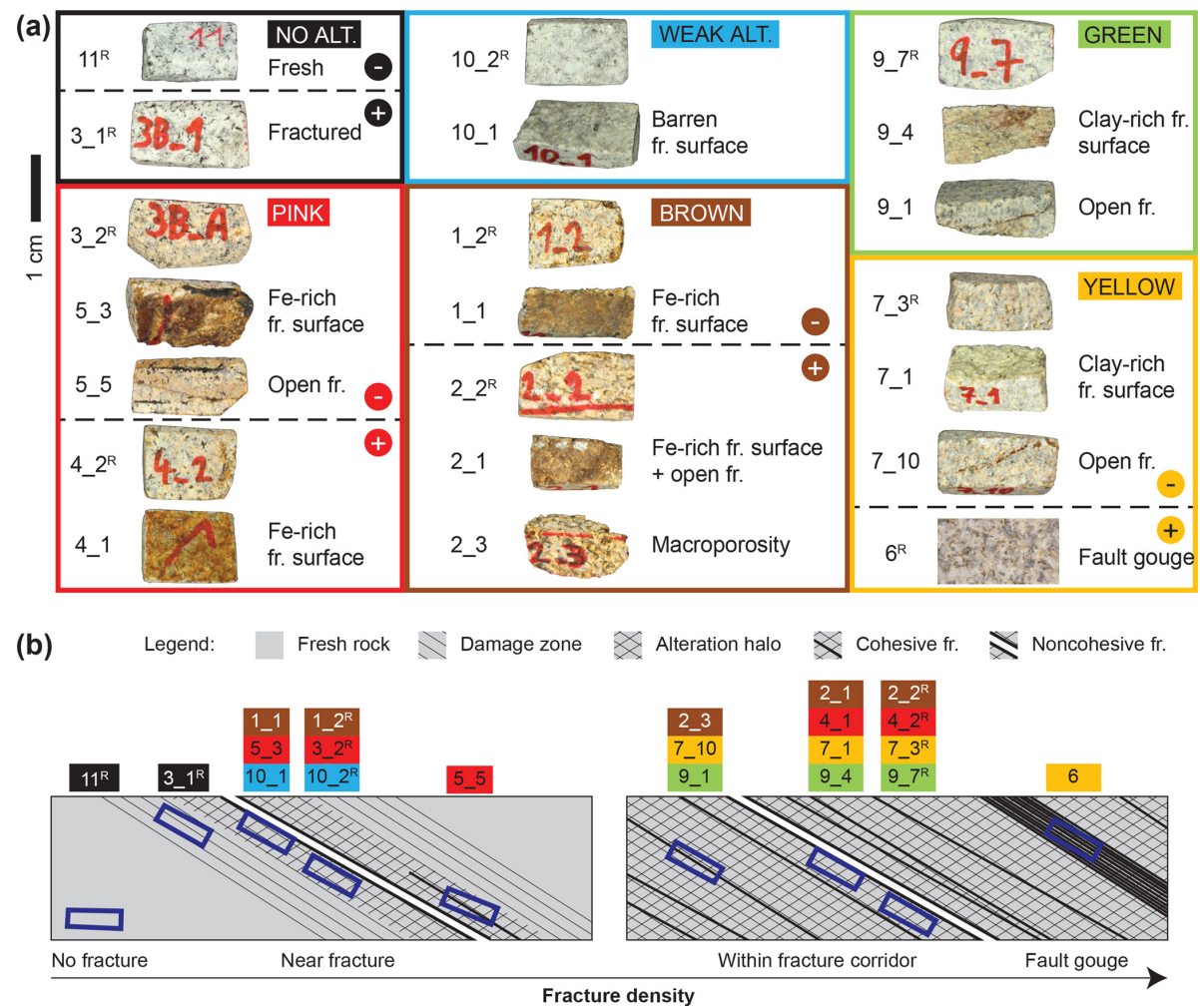

Figure 3. (a) Photographs and parametric description of specimens tested by mercury porosimetry grouped by alteration facies. The dashed lines delimit subgroups of specimens from lower (minus symbol) and higher (plus symbol) fracture density zones; (b) schematic sketch of rock cores and sampled materials showing in a simplified way the position of the specimens within the core samples. Specimens indexed with " $\mathrm{R}$ " were selected as representative of the matrix of the facies. Alt.: alteration, fr.: fracture.

trapped porosity represented by pore-throat arrangements with low throat-to-pore size ratio. Analogously, voids with high throat-to-pore size ratio, including cracks, are free of mercury at this stage since they do not entrap mercury (stage $\mathrm{D}$ in Fig. 4c). Finally, when the pressure is increased again, the mercury can intrude only voids where trapping has not occurred and thus intrudes the free porosity only. Since the mercury reintrusion is technically available during the high pressure analysis only, the free porosity values represent only the microporosity of the specimens. Consequently, to examine the relation between the amount of free porosity and permeability calculated using the model of Katz and Thompson $(1986,1987)$, porosity and median throat-size values calculated from the microporosity throat-size range were used as input for the permeability model.

\subsection{Permeability measurements}

To show the consistency of the calculated permeabilities with experimentally obtained values we present summarized results of permeability measurements. A nitrogen gas permeameter was used working with $1 \mathrm{MPa}$ confining pressure. Samples were plugs $17 \mathrm{~mm}$ in diameter and $16-20 \mathrm{~mm}$ in length. At least three measurements per sample at different constant head pressures $<1 \mathrm{MPa}$ were used for Klinkenberg correction to obtain the real permeability value. See Staněk (2013) for theoretical and experimental details.

\section{Results}

\subsection{Microstructural and mineral optical properties}

The fresh granite features magmatic microstructures with grain size and shape parameters corresponding to the analysis of Staněk et al. (2013). Quartz features an undulatory extinction. K-feldspar features Carlsbad twins and perthite and myrmekite exsolutions. Muscovite is remarked by higher than average grain size. Plagioclase features albite twins. Biotite is euhedral and features strong pleochroism from dark reddish-brown to yellowish-brown colors, interference colors of the third order, straight and fine or absent cleavage planes, and encloses euhedral grains of ilmenite, zircon and monazite (Fig. 5a). The magmatic assemblage features very weak alteration represented by partial or rarely complete chloritization of the minority of biotite grains and by illite in plagioclase grains. The chloritization is demonstrated by an irregular alternation of biotite and chlorite lamellae within the former biotite outline with the lamellae typically having a width 


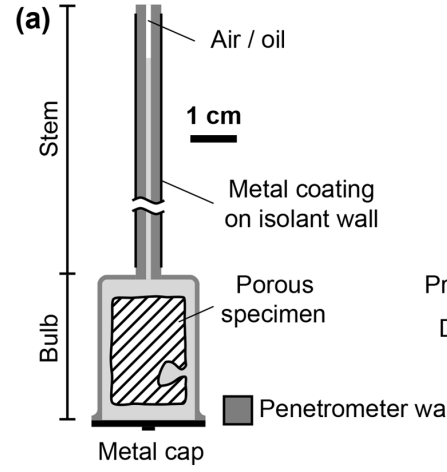

(c)

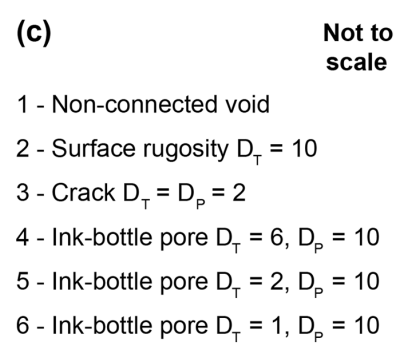

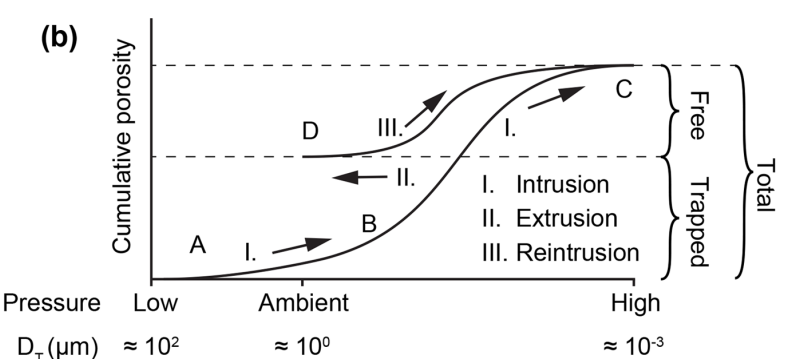

$\mathrm{D}_{\mathrm{T}}(\mu \mathrm{m}) \approx 10^{2} \quad \approx 10^{\circ} \quad \approx 10^{-3}$

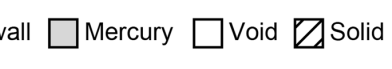

A

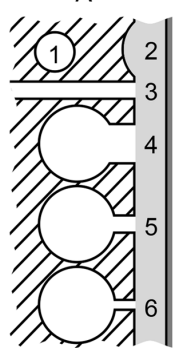

B

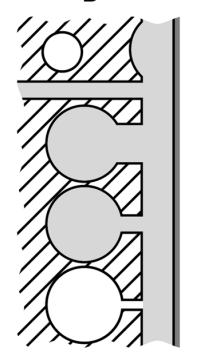

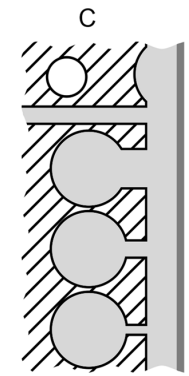

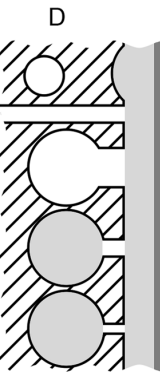

Figure 4. Mercury porosimetry; (a) schematic drawing of a penetrometer (specimen holder); (b) plot of an idealized cumulative porosimetric curve to explain the measurement of connected total, trapped and free porosity by mercury reintrusion, A-D relate to (c); (c) schematic drawings of void spaces in a rock specimen to explain the phenomenon of mercury entrapment with respect to different arrangements of throats in relation to pores. $D_{\mathrm{T}}$ : throat diameter, $D_{\mathrm{P}}$ : pore diameter.

(perpendicular to the basal planes) of $1 / 2$ to $1 / 5$ of the total width of the outline. The shape of the partially chloritized grains is as a consequence modified due to the spiky tips of the chlorite lamellae. This chlorite (hereafter referred to as "chlorite 0") lamellae are characterized by curvilinear cleavage planes, by moderate pleochroism from pale green to pale brown and by the first order lavender blue interference color and are associated with infrequent fine-grained secondary Kfeldspar, rutile and epidote (Fig. 5b). The illite dominantly occurs in the central part of plagioclase grains as isolated fine grains aligned with the plagioclase cleavage planes and features interference colors from the beginning of the first order to the beginning of the second order (Fig. 6e).

The fractured granite shows similar microstructural and mineral optical properties as the fresh granite and differs from the latter by higher crack density (see the next section for details).

The weakly altered granite is characterized by complete chloritization of the former biotite grains at a distance of less than $2 \mathrm{~cm}$ from the fracture surface. This chlorite (hereafter referred to as "chlorite 1") has similar optical properties as chlorite 0 except that the interference colors also comprise the first order light yellow in addition to the lavender blue colors (Fig. 5c). The chlorite 1 grains often feature lenticular lamellae and within the former biotite outline there are numerous fine grains of secondary K-feldspar and rutile.

The green granite is characterized by complete chloritization of biotite, by minor illitization of the chlorite, by ma- jor illitization of plagioclase and by illite infills of fractures. Minor parts of some of the chlorite grains have similar optical properties as chlorite 1 , whereas the chlorite in the green granite (hereafter referred to as "chlorite 2") dominantly features very weak to no pleochroism associated with a very pale brownish color and a first order light yellow interference color (Fig. 5d). In addition, both in PL and XPL, the appearance of the chlorite 2 grains seems to be biased towards darker colors due to homogeneously distributed dark red particles less than $1 \mu \mathrm{m}$ in size. The minority of chlorite 2 grains microstructurally unrelated to a fracture feature partial recrystallization to fine-grained illite (Fig. 6a). At places where illite-filled fracture cuts a chlorite grain, a part of it near $(100 \mu \mathrm{m})$ the fracture is illitized (Fig. 6b). The illite in plagioclase occurs in fan-shaped aggregates distributed along the plagioclase cleavage planes (Fig. 6f). The illite grains filling fractures do not feature a shape-preferred orientation (Fig. 6c). Whereas some of the fractures or some parts of them are filled with illite only, other fractures or other parts of the fractures feature illite at the granite walls and dark red, probably amorphous, material in their central parts. Some of the largest parts of the fractures filled with the dark red material feature circular to elongated cavities in the center.

The brown granite is characterized by complete chloritization of biotite and by moderate illitization of plagioclase. The chlorite in the brown granite (hereafter referred to as "chlorite 3") features strong pleochroism from a dark green to pale brown color and the third order interference colors (Fig. 5e). 

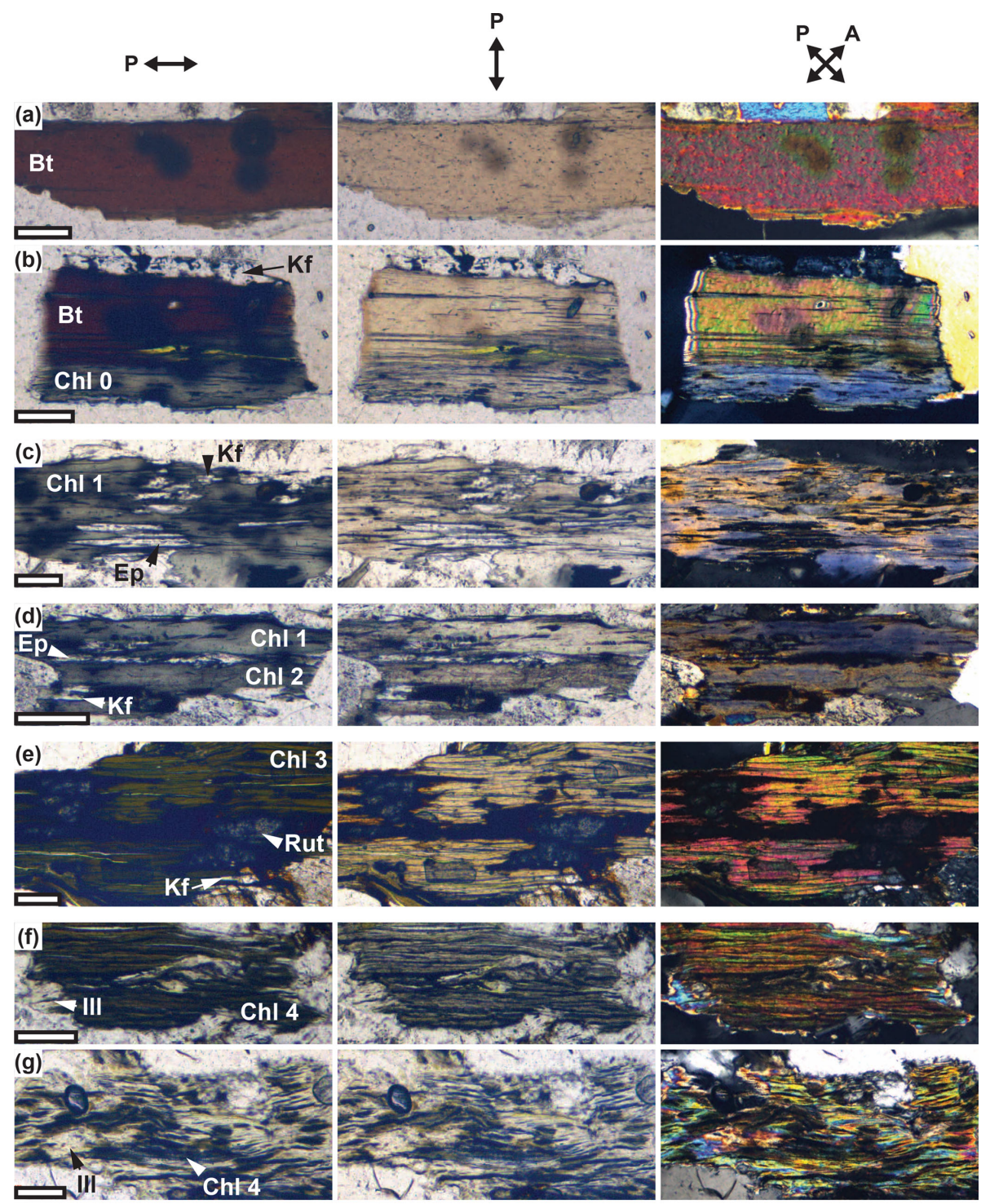

Scale bar $=100 \mu \mathrm{m}$

Figure 5. Polarized light photomicrographs showing optical properties of biotite and its alteration products. The double-headed arrows show polarization direction of polarizer $(\mathrm{P})$ and analyzer $(\mathrm{A})$ for each column; (a) biotite and (b) biotite partially replaced by chlorite (Chl 0$)$ in fresh granite; (c) chlorite (Chl 1) in weakly altered granite; (d) chlorite (Chl 1 and $\mathrm{Chl} 2$ ) in green granite; (e) chlorite (Chl 3) in brown granite; (f, g) chlorite ( $\mathrm{Chl} 4)$ and illite in yellow granite. Bt: biotite, Kf: K-feldspar, Ep: epidote, Rut: rutile and Ill: illite.

The chlorite 3 grains feature open cleavage planes with large $(50-100 \mu \mathrm{m})$ grains of secondary rutile and fine $(10-50 \mu \mathrm{m})$ grains of secondary K-feldspar. The minority of the chlorite 3 grains feature illitized lamella tips. The illitization of the plagioclase in the brown granite is characterized by a homogeneous distribution of isolated fine grains of illite aligned with the plagioclase cleavage planes (Fig. 6g).

The yellow granite is characterized by complete chloritization of biotite, by minor to major illitization of the chlorite, by major illitization of plagioclase and by illite infills of fractures. The pseudomorphs after biotite in the yellow granite are composed of chlorite (hereafter referred to as "chlorite
4") and illite with the illite occupying from approximately $10 \%$ to $90 \%$ of the area within the former biotite outline. The chlorite 4 lamellae feature moderate pleochroism from olive green to pale brown and third order interference colors, whereas the illite lamellae are colorless in PL and feature second order interference colors (Fig. 5f). The pseudomorphs with the lowest illite proportion are characterized by irregular alternation of chlorite and illite lamellae typically having a width of $1 / 10$ to $1 / 20$ of the total width of the pseudomorph and feature illitized tips of the chlorite 4 lamellae. In pseudomorphs with the highest proportion of illite, irregular lamellae-like regions with a similar green color to chlorite 4 

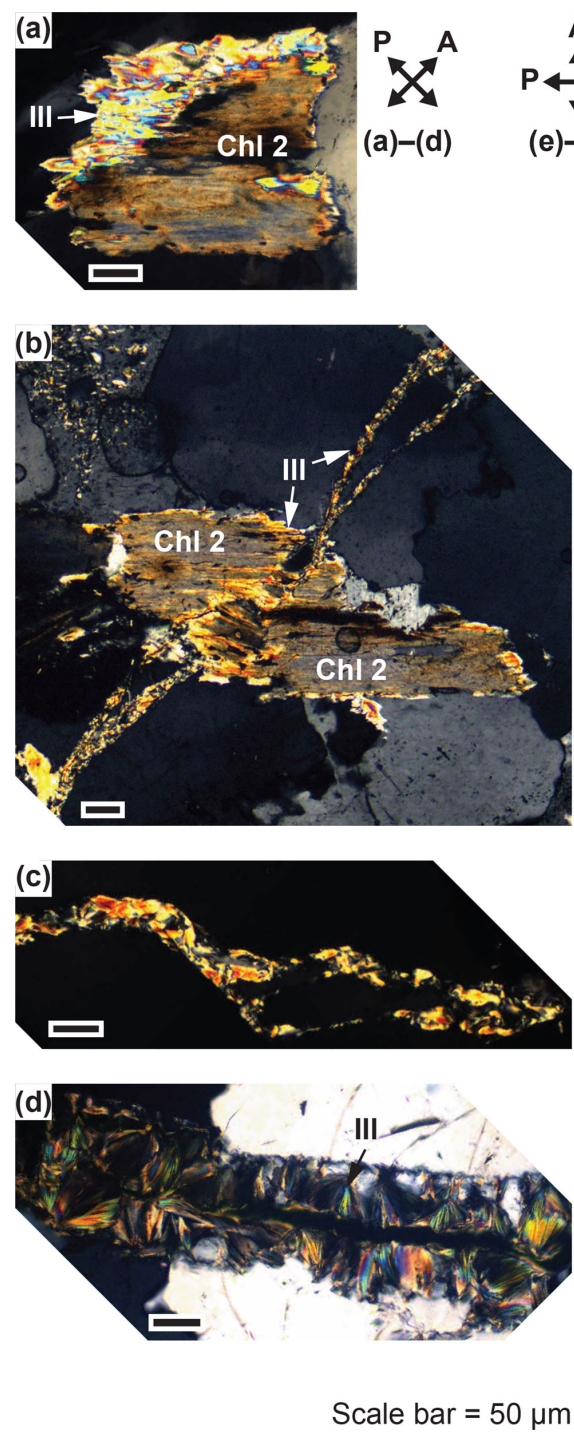
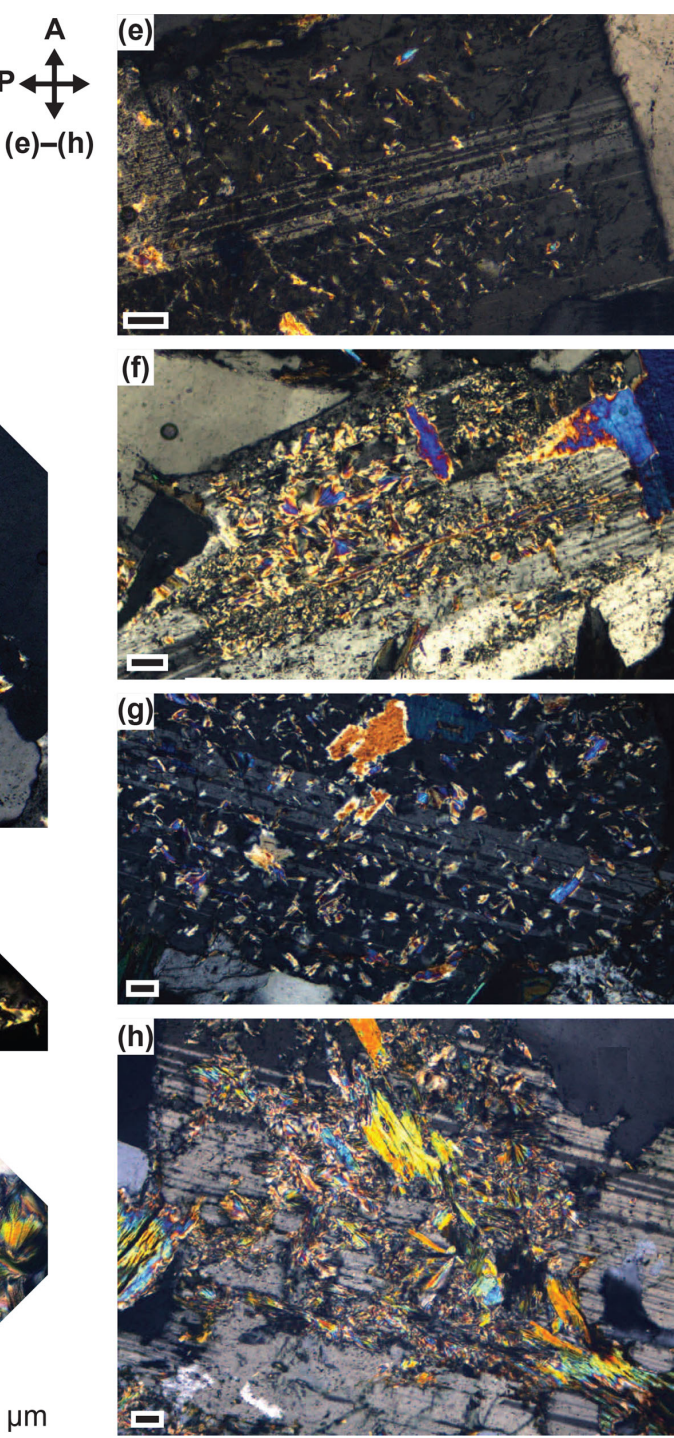

Figure 6. Polarized light photomicrographs showing microstructural position of illite. The double-headed arrows show polarization direction of polarizer (P) and analyzer (A). Partial chlorite (Chl 2) illitization unrelated (a) and related (b) to illite-filled crack (c) in green granite; (d) illite-filled crack in yellow granite; (e) isolated grains of illite in the core of plagioclase in fresh granite; (f) connected fan-shaped aggregates of illite aligned with plagioclase cleavage in green granite; $(\mathbf{g})$ isolated grains of illite homogeneously distributed in plagioclase in brown granite; (h) aggregates of illite in plagioclase in yellow granite. Ill: illite.

occur, though with no pleochroism and partially dimmed in XPL independent of the orientation with respect to the polars (Fig. 5g). The pseudomorphs also feature secondary rutile and infrequent K-feldspar. The illite grains in fractures occur with their basal planes perpendicular to the fracture walls or in fan-shaped aggregates radiating from the fracture walls (Fig. 6d). The illite in plagioclase occurs in irregular and interconnected aggregates containing grains of various sizes from undistinguishable under a light microscope to about $100 \mu \mathrm{m}$ (Fig. 6h).

The pink granite is characterized by orange-red infills of cracks cutting an otherwise unaltered microstructure characteristic of the fresh granite.

\subsection{Connected porosity structure}

As observed in thin sections using FL microscopy, the connected porosity of the studied granite is mainly made of cracks (low aspect ratio), pores (high aspect ratio) and distributed porosity within fine-grained phyllosilicate-rich aggregates. We distinguish the following types of cracks. A "Granular crack" terminates within or on the grain boundaries. "Cleavage crack" is a granular crack parallel to mineral cleavage. "Grain boundary crack" follows grain boundaries and its length typically does not exceed 2 times the average grain size. "Intergranular crack" is a continuous compound of the other types of cracks. 

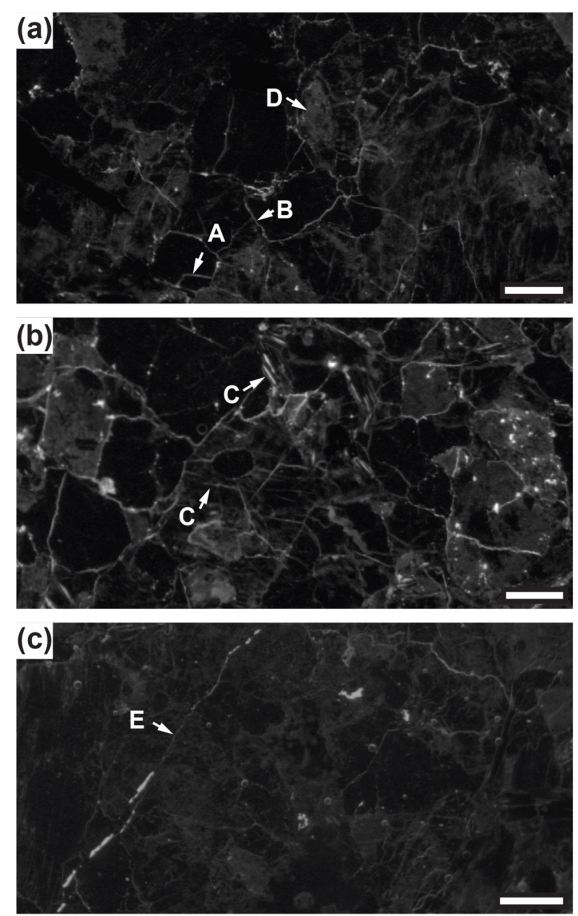

Scale bar $=1 \mathrm{~mm}$
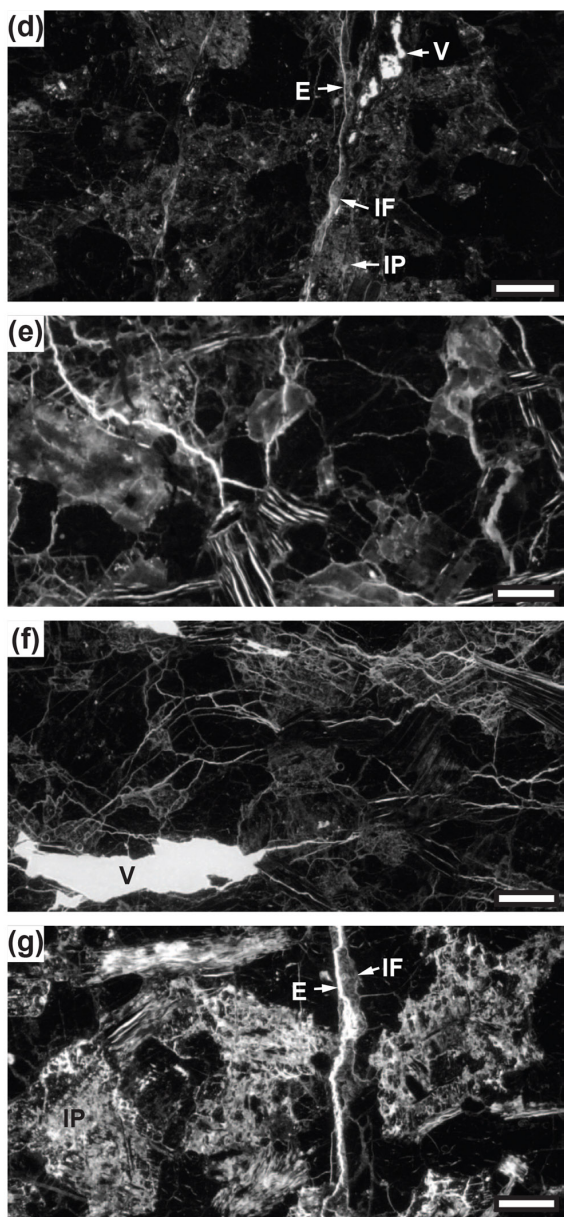

Figure 7. UV-fluorescent light photomicrographs showing microstructural position of connected porosity. Representative situations for fresh granite and pink granite near a single fracture (a), for fractured and weakly altered granite (b), for pink granite in a fracture corridor (c), for green granite (d), for brown granite near a single fracture (e), for brown granite in a fracture corridor (f) and for yellow granite in a fracture corridor (g). D: distributed porosity in plagioclase, B: grain boundary crack, A: intragranular crack, C: cleavage crack, E: intergranular crack, V: cavity, IF: illite infills in fracture and IP: illite aggregate in plagioclase.

In the fresh granite, the connected porosity is restricted to isolated grain boundary and granular cracks and scarce phyllosilicate aggregates in plagioclase grains (Fig. 7a). Compared to the latter, the fractured and the weakly altered granite show more frequent cracks of all types associated with intergranular cracks made of short segments of various orientations (Fig. 7b). Within the pink granite, the connected porosity in the single fracture-related samples occurs in the same structural positions as in the fresh granite, while in the fracture-corridor-related sample the porosity also occurs in infrequent intergranular cracks (Fig. 7c). In the green granite, the connected porosity dominantly occurs in intergranular cracks, in the illite aggregates in plagioclase, in the illite infills of fractures and in the cavities associated with the largest fractures (Fig. 7d). The connected porosity in the single fracture-related brown granite occurs in the same structural positions as in the fractured granite and in frequent intergranular cracks (Fig. 7e). The connected porosity in the fracture- corridor-related brown granite also occurs in elongated cavities of tens to hundreds of microns in size, which dominantly occur at a distance of less than $1 \mathrm{~cm}$ from the master fracture surface to which they are subparallel (Fig. 7f). Within the yellow granite, the connected porosity occurs in frequent cracks of all types and also in the illite infills of fractures and in the illite aggregates in plagioclase (Fig. $7 \mathrm{~g}$ ).

\subsection{Chemical composition of minerals}

Selected aspects of the chemical analyses are plotted on graphs in Fig. 8 and averaged representative analyses including structural formulae of the principal alteration phases are shown in Table 1.

For all facies with biotite (fresh, fractured and pink granite), the compositions of unaltered biotite grains as well as of biotite lamellae in partially chloritized grains fall in the field of siderophyllite of the biotite classification graph (Fig. 8a). 


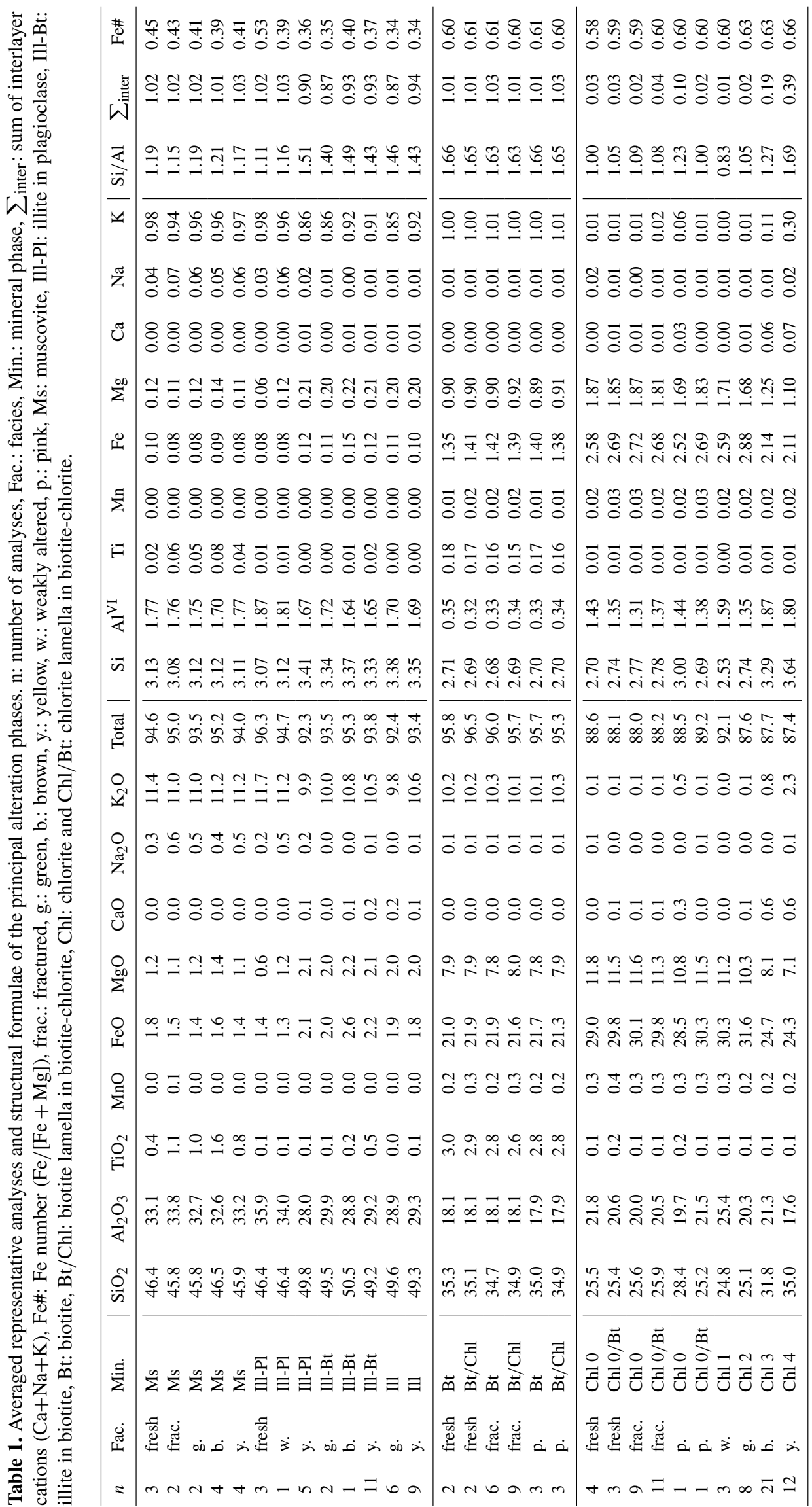



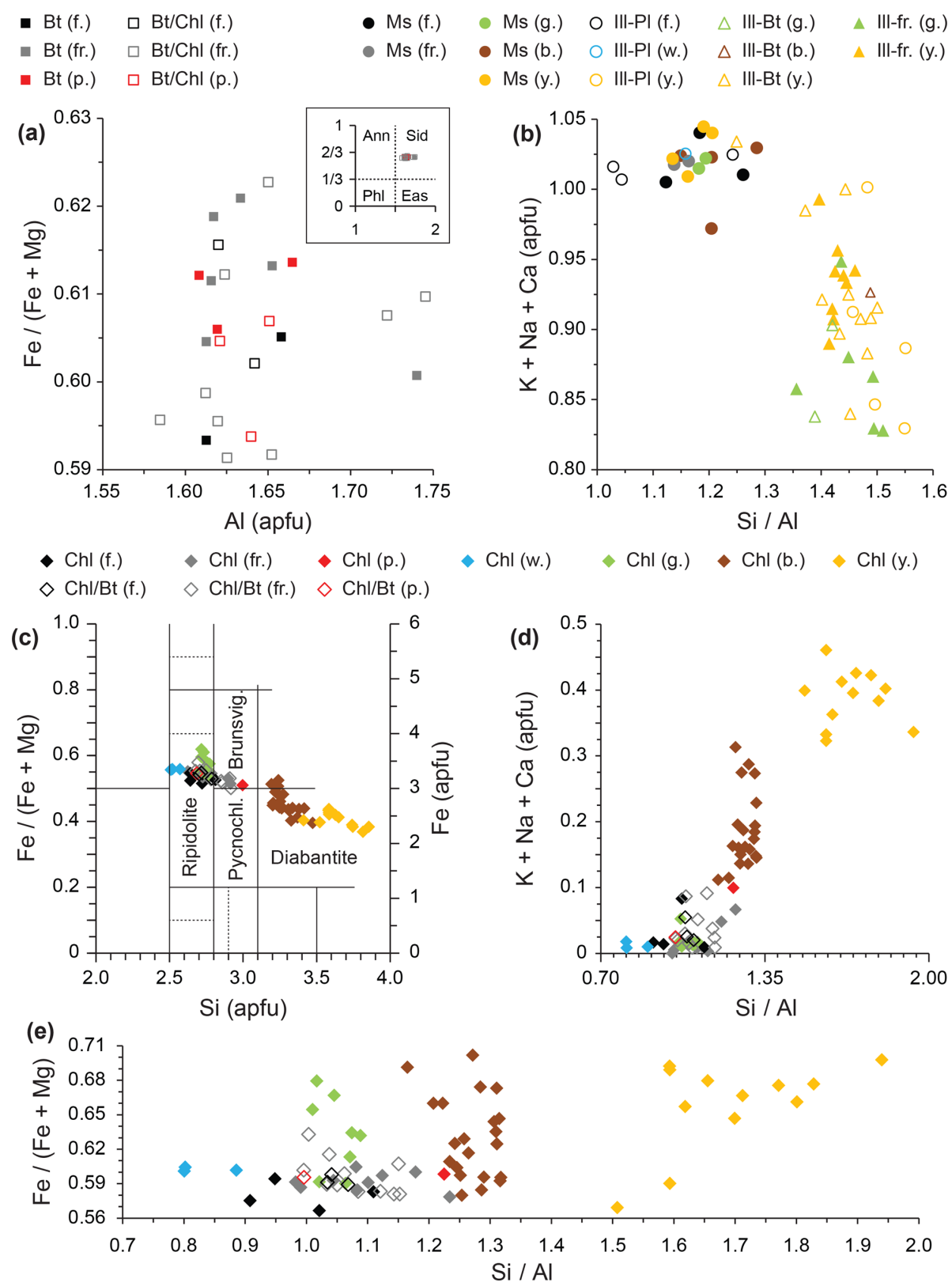

Figure 8. Chemical composition of analyzed minerals. (a) Biotite (Bt) and biotite lamella in chloritized biotite (Bt/Chl); (b) muscovite (Ms), illite in plagioclase (Ill-Pl), in pseudomorph after biotite (Ill-Bt) and in fracture (Ill-fr.); (c, d, e) chlorite (Chl) and chlorite lamellae in chloritized biotite (Chl/Bt), (c) classification diagram after Hey (1954). Atoms per formula unit (apfu) calculated based on 11 oxygens (a, b) and 14 oxygens (c, d, e). Facies - f.: fresh, fr.: fractured, p.: pink, g.: green, b.: brown, y.: yellow, w.: weakly altered. Ann: annite, Sid: siderophyllite, Phl: phlogopite, Eas: eastonite, Brunsvig.: brunsvigite and Pycnochl.: pycnochlorite.

For all facies, the grains of muscovite have a similar composition (Fig. 8b). In terms of atoms per formula unit (apfu) of interlayer cations $(\mathrm{K}, \mathrm{Na}, \mathrm{Ca})$ the grains of illite in plagioclase in the fresh and in the weakly altered granite have a composition similar to the muscovite. In the green, yellow and brown granite the illite grains contain fewer interlayer apfu and have higher $\mathrm{Si} / \mathrm{Al}$ ratio as compared to muscovite. The illite in the yellow granite has more interlayer apfu than that in the green granite and the two groups show a similar $\mathrm{Si} / \mathrm{Al}$ ratio.

In the chlorite classification graph (Hey, 1954) the chlorite compositions dominantly fall in the fields of ripidolite, brunsvigite and diabantite (Fig. 8c). In the brown and the yellow granite the chlorite analyses show, respectively, up to 0.029 and $0.043 \mathrm{~K}+\mathrm{Na}+\mathrm{Ca}$ cation molar fractions corresponding to 0.31 and 0.46 apfu when recalculated based on 14 oxygens (Fig. 8d). The chlorites from the latter two facies 
also feature a higher $\mathrm{Si} / \mathrm{Al}$ ratio. In terms of $\mathrm{Fe} /(\mathrm{Fe}+\mathrm{Mg})$, the chlorites and chlorite lamellae in the fresh, fractured and weakly altered granite feature a narrow span and the values of the former two are equal to or lower than those of the corresponding biotites and biotite lamellae (Fig. 8e and a). In the green, brown and yellow granite the chlorites feature a larger span of $\mathrm{Fe} /(\mathrm{Fe}+\mathrm{Mg})$ values that are mostly higher than for the fresh, fractured and weakly altered granite.

The red infill of fractures in the pink granite is rich in iron with no significant amount of other elements (Fig. 9).

\subsection{Porosimetry}

The measured throat size distributions (TSD) are plotted in Fig. 10 and the bulk specimen values of total porosity, free porosity, volumetric median throat size (MTS), bulk density and calculated permeability are plotted in Fig. 11.

The fresh granite features the narrowest TSD with significant incremental porosity between approximately 0.02 and $0.4 \mu \mathrm{m}$ (Fig. 10a), the lowest total porosity of $0.3 \%$ and MTS of $0.23 \mu \mathrm{m}$ (Fig. 11a).

Compared to the latter, the fractured and the weakly altered granite feature higher incremental porosities and broader TSDs with additional porosity accessible through throats of 0.2 to $0.8 \mu \mathrm{m}$ in size (Fig. 10a). These two facies feature similar total porosities around $0.8 \%$ and the MTS of the weakly altered granite of $0.21 \mu \mathrm{m}$ is close to that of the fresh granite, while the fractured granite features a higher value of $0.27 \mu \mathrm{m}$. The two tested specimens of the weakly altered granite differing by the presence (10_1) or absence (10_2) of the superficial layer on the fracture surface do not differ significantly in terms of the TSD shape or the values of total porosity and of MTS (Fig. 10b).

Compared to the fractured granite, the matrix of the pink granite near a single fracture features a shift of the TSD towards smaller sizes with approximately 2 times lower MTS of $0.12 \mu \mathrm{m}$ and lower total porosity of $0.5 \%$. However, the TSD of the pink granite near a single fracture may be very different when a porous fracture surface (5_3) or a partially open fracture (5_5) is included in the specimen and the macroporosity is taken into account (Figs. 10b and 11a). As compared to the matrix of the pink granite near a single fracture, the matrix of the pink granite in a fracture corridor features a shift of the TSD towards the larger sizes and additional porosity accessible through throats of up to $2 \mu \mathrm{m}$ in size and has about 2 times higher porosity and MTS. Comparing the two specimens from within the pink granite in a fracture corridor, the one with the natural fracture surface rich in iron oxides (4_1) features lower incremental porosities for throats larger than $0.4 \mu \mathrm{m}$ and also lower total porosity and lower MTS (Fig. 11a).
The green granite is remarked by high incremental porosities at the low end of the measured throat-size spectrum; more precisely, it features the highest values for throats smaller than $0.05 \mu \mathrm{m}$. This fact is reflected in the porosity vs. MTS plot showing that for a given porosity the green granite features the lowest MTS. Comparison of the green granite specimens shows that both the clay-rich fracture surface and the partially open fracture are associated with higher incremental porosities in the submicron range and that the open fracture is associated with important macroporosity. The total porosities and MTSs range, respectively, from $1.4 \%$ and $0.1 \mu \mathrm{m}$ for the matrix-representative specimen (9_7) to $2.8 \%$ and $0.26 \mu \mathrm{m}$ for the specimen with partially open fracture (9_1).

The matrix of the yellow granite in the fracture corridor features the highest incremental porosities in the throat-size range 0.04 to $0.4 \mu \mathrm{m}$, total porosity of $2.5 \%$ and MTS of $0.24 \mu \mathrm{m}$. The specimen with the clay-rich fracture surface (7_1) features higher incremental porosities in the range 0.4 to $4 \mu \mathrm{m}$ associated with a total porosity of $3.8 \%$ and MTS of $0.56 \mu \mathrm{m}$. The fracture-bearing specimen (7_10) features the highest total porosity of $4.3 \%$ and several important peaks in the throat-size range between 1 and $100 \mu \mathrm{m}$. The yellow granite fault gouge specimen globally features the highest incremental porosities in the throat-size range from 0.4 to $4 \mu \mathrm{m}$ and important porosity accessible by larger throats. With the exception of the brown granite and of the porous fracture surface of the pink granite (specimen 5_3), the yellow granite fault gouge features the highest MTS of $0.94 \mu \mathrm{m}$.

The brown granite is characterized by a broad TSD taking into account either of its subfacies. For the brown granite near a single fracture the broad TSD is associated with rather low total porosities from $1.5 \%$ to $1.6 \%$, whereas the fracture corridor specimens feature total porosities from $2.9 \%$ up to the globally highest value of $6.5 \%$ associated with one of the highest values of MTS of $2.9 \mu \mathrm{m}$. The specimen designed to represent the zone with the cavity-related macroporosity (2_3) features the highest incremental porosities at the high end of the measured spectrum and with its broad distribution and the very high median throat-size value $(3-4 \mu \mathrm{m})$ it resembles the pink granite specimen 5_3 carrying the porous iron-rich fracture infill although the brown granite specimen features 2 times higher total porosity (Fig. 11a).

Concerning the entire MIP specimen collection, the plot of throat diameter vs. total porosity (Fig. 11a) reveals two distinct trends. The matrix-representative specimens of facies without intensive illitization (fresh, fractured, weakly altered, pink) feature low porosities (up to approximately $1 \%$ ) and for a given porosity they show high MTS. On the other hand, the facies with intensive illitization (green, yellow) feature matrix porosities between approximately $1.5 \%$ and $4.5 \%$ while they have relatively low MTS for a given porosity. These trends highlight one of the effects of the illitization described above: formation of void space structures with important porosity and with small throats. 

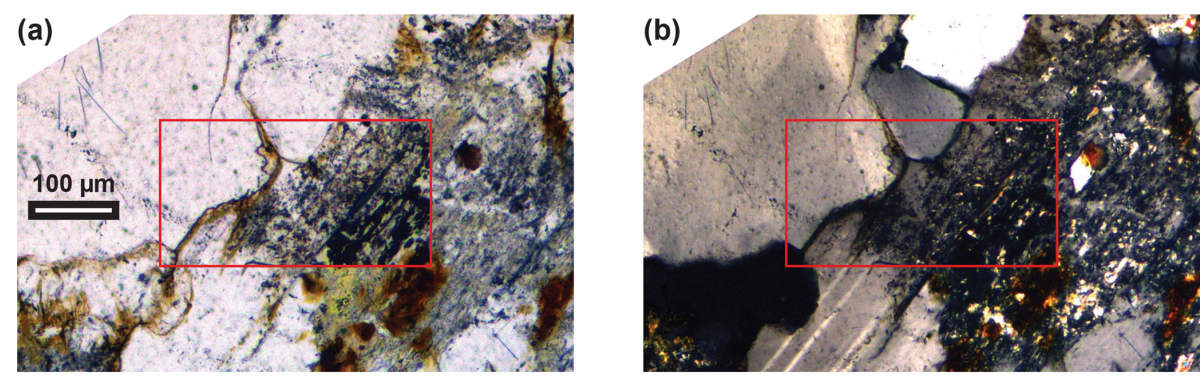

(c)
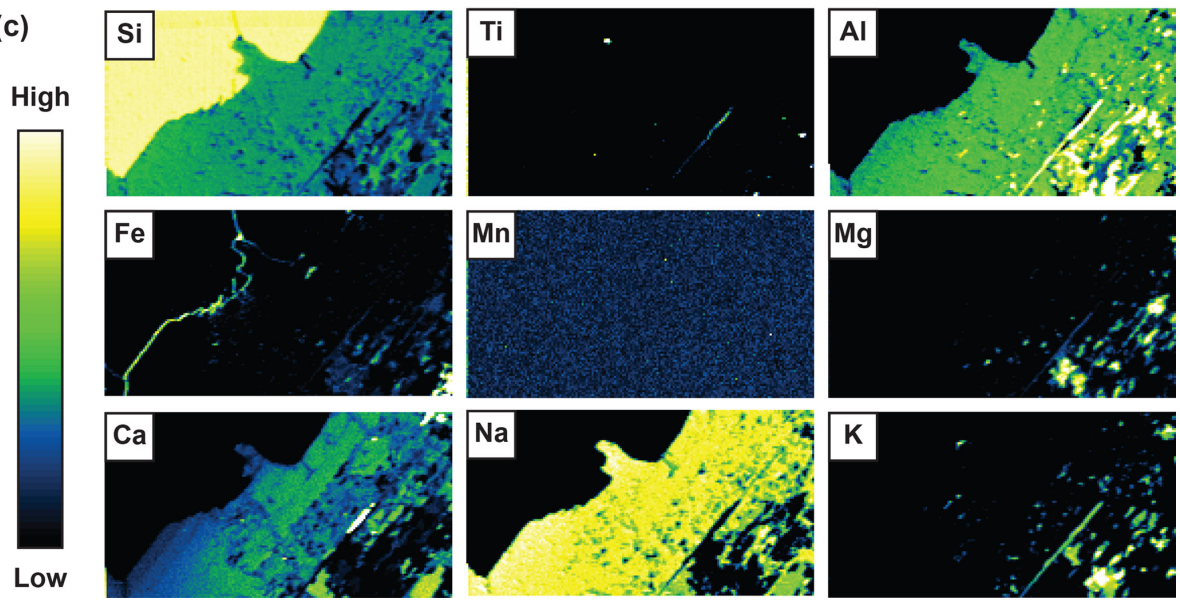

Figure 9. Microphotographs and elemental maps showing the Fe-rich material filling fractures in the pink granite. (a) polarized light, (b) cross-polarized light, (c) elemental maps for the region delimited by the red rectangle in (a) and (b).

The values of bulk density are plotted for each specimen as a function of total porosity in Fig. 11b. Based on extrapolation of the dataset towards zero porosity, the density of the tested granite in a virtual nonporous state is $2.637 \mathrm{~g} \mathrm{~cm}^{-3}$.

\subsection{Calculated permeability}

The permeability values calculated based on the microporosity range using the model of Katz and Thompson (1986, 1987) are plotted as a function of free microporosity for each specimen in Fig. 11c. Among a large set of models using MIP data to calculate the permeability value (Buiting and Clerke, 2013; Nooruddin et al., 2014), this one is the simplest and the most accurate for crack network in granite (Gao and Hu, 2013; Katz and Thompson, 1986, 1987). Note that the two quantities are independent: the permeability was calculated from the measured total microporosity and the associated MTS whereas the free microporosity was measured by mercury reintrusion and represents only the void spaces with high throat to pore size ratio such as cracks. It can be seen that low free porosity (below $0.4 \%$ ) is associated with low permeability (ca. from $10^{-19}$ to $10^{-18} \mathrm{~m}^{2}$ ) and high free porosity (above $0.7 \%$ ) with high permeability (ca. from $10^{-17}$ to $10^{-16} \mathrm{~m}^{2}$; cf. Fig. 11c). Few exceptions from this trend are represented by specimens with relatively high porosity and at the same time with an important proportion of void space with low throat to pore size ratio. These cal- culated values are confirmed by a set of measured values on samples of different facies. The ranges of the measured values are coherent with the calculated ones and highlight the validity of the used model and of the pore network.

In greater detail, two groups of specimens can be distinguished based on the proportionality between the two quantities. One group is represented by low porosity specimens and comprises fresh, fractured, weakly altered, pink and green granite with the exception of the highly porous fracture infill from the pink granite facies (specimen 5_3). This group features a steep increase in permeability with increase in free porosity and can be divided into two subgroups: specimens from the green granite and the other specimens. For the green granite the permeability is lower at a given free porosity as compared to the other specimens. For example, the fractured granite and the pink granite in the fracture corridor (specimens 3_2 and 4_2) yield a permeability of $2 \times 10^{-18} \mathrm{~m}^{2}$ at ca. $0.2 \%$ free porosity, whereas such permeability corresponds to ca. 2 times higher free porosity in the green granite (specimen 9_1). The other group is represented by high porosity specimens comprising the brown and the yellow granite. The high porosity group features a less-steep increase in permeability with free porosity and the specimen of brown granite with macroscopic cavities (2_3) indicates that the permeability may increase only slightly or not at all with a further increase in free porosity. For example, permeability of ca. 


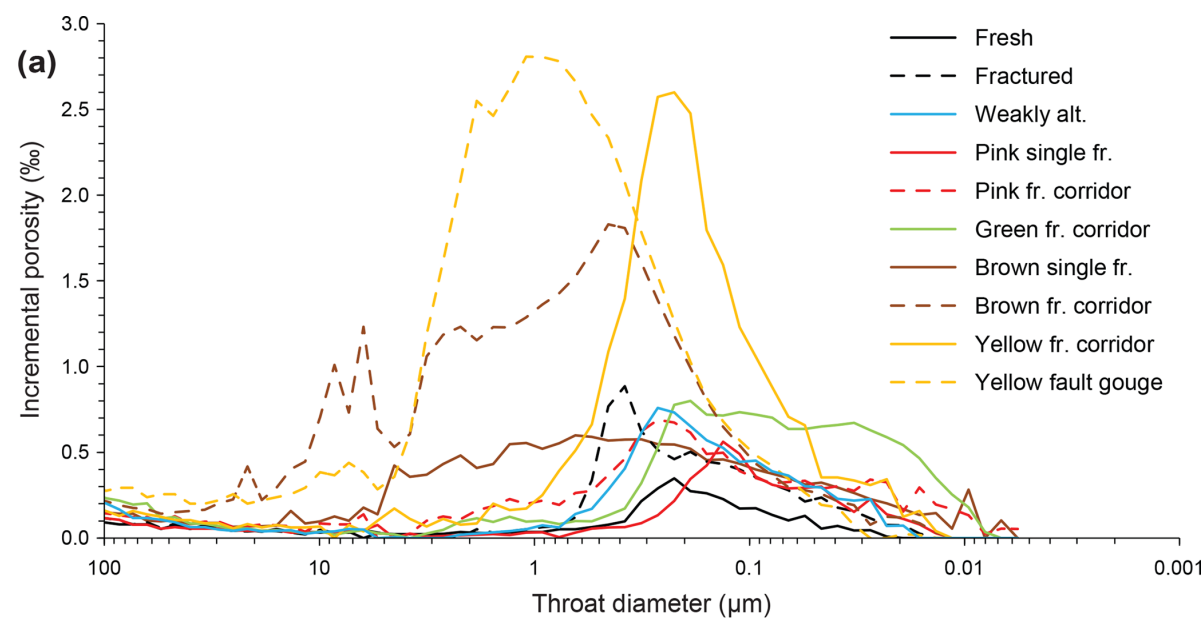

(b)
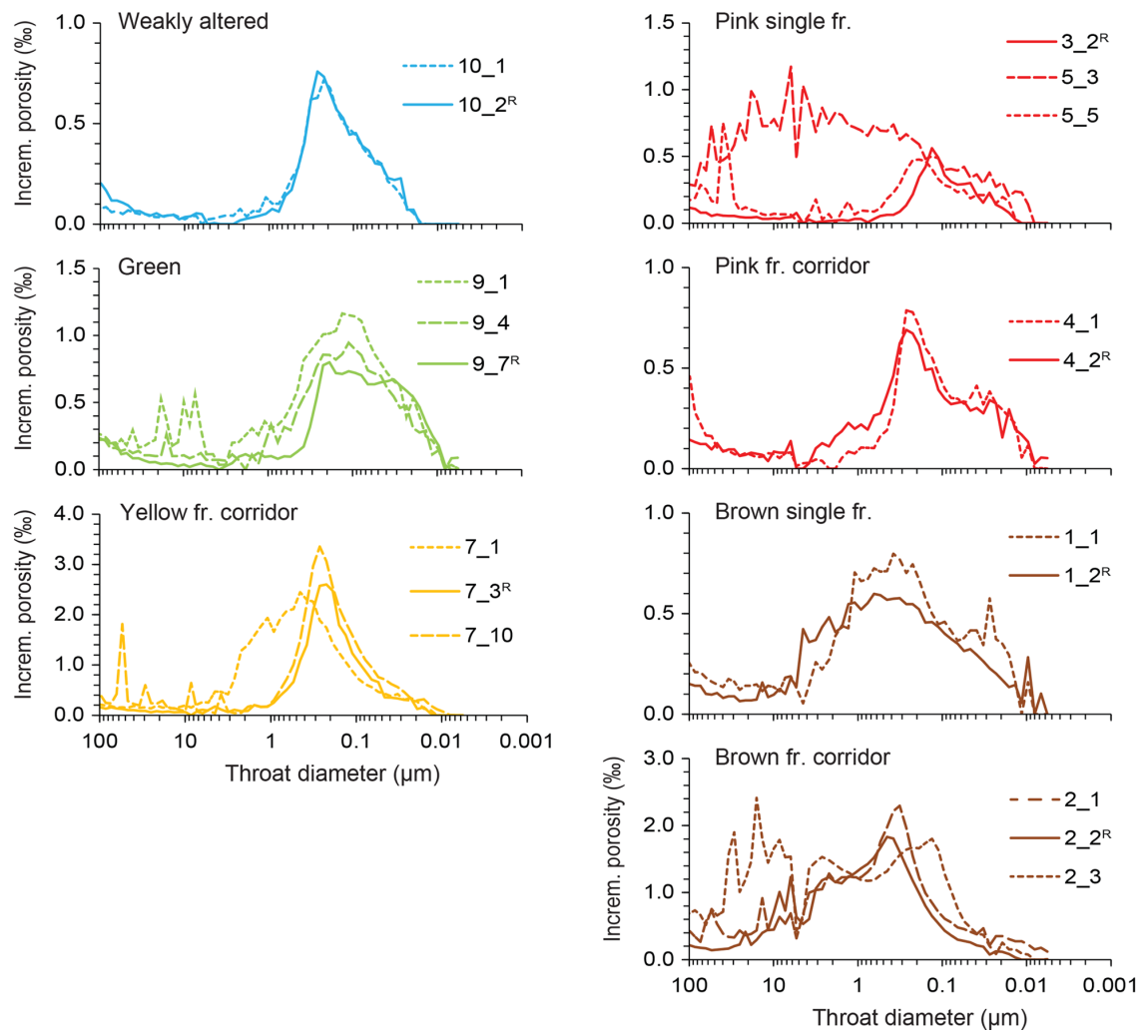

Figure 10. Incremental porosimetric curves showing throat size distributions of the connected porosity of (a) different facies and of (b) specific fracture-related features within the altered facies. From the latter, specimens indexed with "R" were selected as representative of the facies matrix and plotted in (a), compare with Fig. 3. Fr.: fracture, alt.: altered.

$3 \times 10^{-17} \mathrm{~m}^{2}$ corresponds to free porosity of $1.0 \%\left(2 \_1\right)$ but a similar permeability value corresponds to the highest free porosity of $1.4 \%$ (2_3). The permeability of the latter specimen, which is relatively low with respect to its free porosity, can also be due to the fact that the permeability is less dependent on cavities (large pores with high aspect ratio) than on cracks, which are the most remarked porosity feature of most of the other specimens.

\section{Discussion and synthesis}

The aim of this paper is to better describe the porosity network developed at the top of a granite batholith and especially the one developed at the bottom of a sedimentary basin. Another aim is to propose a proxy for the porosity estimation using the quality of biotite alteration, which may be helpful 

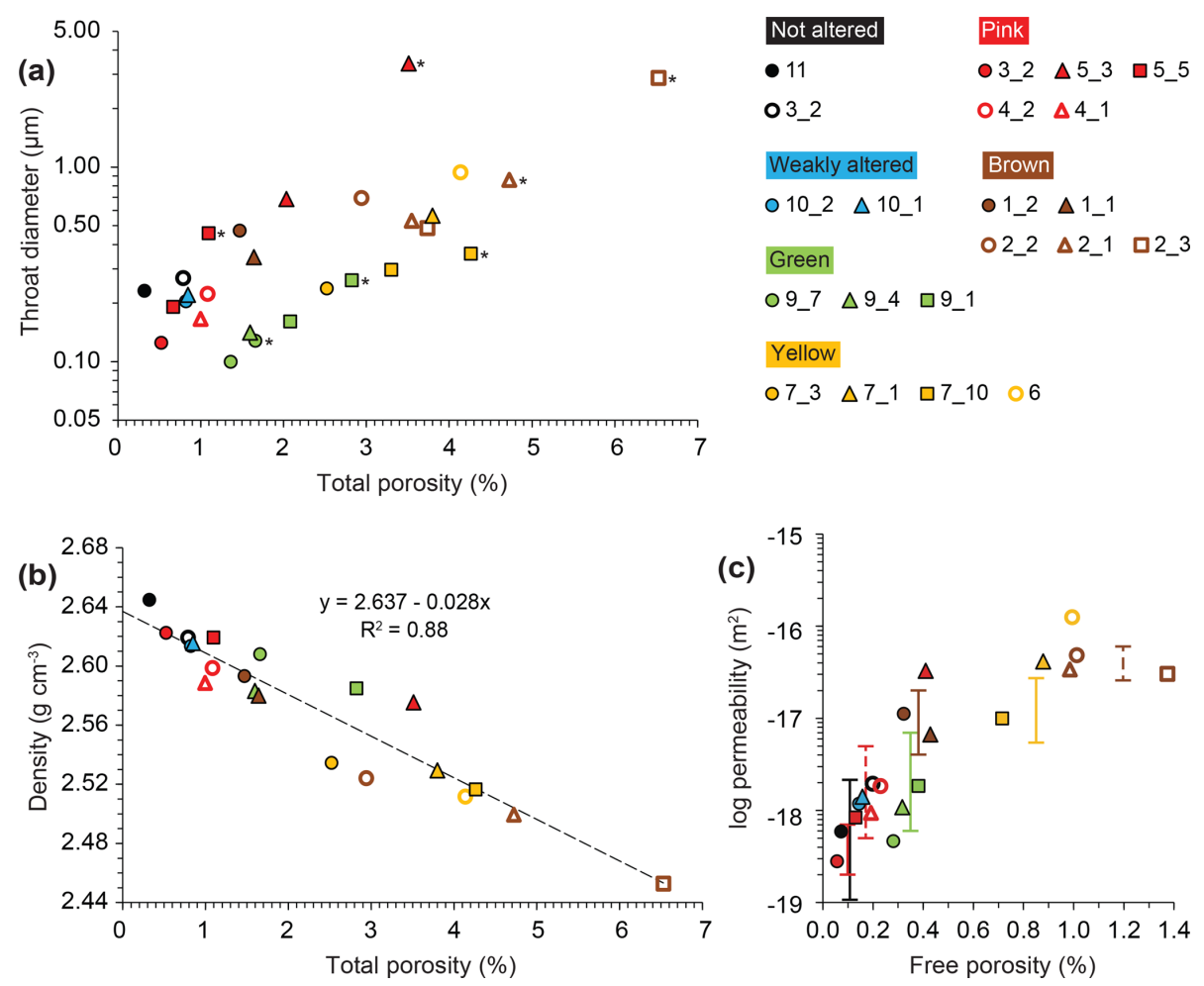

Figure 11. Plots of measured throat diameter, porosity, density and calculated permeability. (a) Volumetric median throat diameter versus total porosity. For all specimens the values were calculated for the throat diameter interval $0.005-5 \mu \mathrm{m}$ and for specimens with macroscopic voids also for the interval $0.005-300 \mu \mathrm{m}$ (denoted by an asterisk to the right of the symbols); (b) bulk density versus total porosity. Total porosity calculated for the throat diameter intervals $0.005-5$ and $0.005-300 \mu \mathrm{m}$ for specimens without and with macroscopic voids, respectively; (c) point symbols: permeability calculated after Katz and Thompson $(1986,1987)$ from the total porosity and median throat diameter (calculated for throat diameter interval $0.005-5 \mu \mathrm{m}$ ) versus free porosity measured by mercury reintrusion (failed for specimen $7 \_3$ ), bars: intervals of permeability measured by gas permeametry on plugs.

to recognize fault zones and weathered layers during drilling operations without coring.

\subsection{Organization of the facies and structures}

The Melechov pluton of an S-granitic composition emplaced at shallow crust level at ca. 330-320 Ma (Žák et al., 2011, 2014) was affected by a large set of brittle deformations with fault and fracture corridors, alteration processes with hydrothermal fluid flows mainly in brittle structures and weathering with meteoritic fluids in the upper part of the profile. The studied core of the drilling project crosscuts these different facies.

Below $65 \mathrm{~m}$ b.1.s. the fracture corridors are mainly composed of fractures with dip higher than $30^{\circ}$ and dominantly feature gray granite (Fig. 2).

From the top to $65 \mathrm{~m}$ b.l.s., there is a complex association of structures and facies including those induced by fault activity and hydrothermal processes and those induced by weathering processes. In the first group there are two high fracture density zones with steeply dipping fractures. One is between 20 and $25 \mathrm{~m}$ b.l.s. associated with the yellow fa- cies developed under weathering conditions and affecting hydrothermal alteration facies in a fault zone. The fracture orientation data from the acoustic borehole image (Lexa and Schulmann, 2006) available down from $22.5 \mathrm{~m}$ b.l.s. suggest that samples 6 and 7 (yellow granite) are associated with the fractures of set 3 (Fig. 2). The other fracture zone, between 42 and $57 \mathrm{~m}$ b.l.s., is larger and is composed of the green hydrothermal facies more or less preserved from the weathering. This fracture zone corresponds to set 4 , the fractures of which are frequently faults with infills carrying kinematics indicators (Lexa and Schulmann, 2006). The weathering alteration affected the highly weathered facies at the top of the profile (brown facies) and the moderately weathered facies below (pink facies). Out of the high fracture density zones, this upper part of the profile is characterized by several corridors with low density of fractures with both gentle and steep dip (cf. Fig. 2). The large set of flat or gently dipping fractures formed during the weathering as exfoliation joints. The steeply dipping fractures belong to sets 1 and 2 with mainly subvertical joints induced by the pluton shrinkage due to cooling (Lexa and Schulmann, 2006; Staněk, 2013). 
The fracture zone at $70 \mathrm{~m}$ depth, consisting mainly of gently dipping fractures, is currently described at the bottom of the weathering profile corresponding to the upper fissured zone (Wyns et al., 2004). The weathering profile is described in several places to result from downward propagation of the structural and petrographic transformations along structural pre-discontinuities (Jamtveit et al., 2011; Lachassagne et al., 2011; Walter et al., 2018).

\subsection{Constrains on timing of fracturing and alteration events}

The oldest brittle fractures are manifested by moderately dipping pegmatite and aplite dikes some of which were later reactivated (Lexa and Schulmann, 2006; Staněk, 2013) and the subvertical joints induced by the pluton shrinkage due to cooling (sets 1 and 2). The formation of the latter two sets overlaps with the pluton uplift as interpreted from associated fractographic features (Lexa and Schulmann, 2006; Staněk, 2013).

In the field, the majority of fractures of sets 1 and 2 do not contain the late-magmatic products. This corresponds to the case of the weakly altered granite characterized by chloritized fracture wall and by barren fracture surface sampled near a steep fracture with dip direction $110^{\circ}$ according to the acoustic borehole image and thus probably belonging to fractures of set 2 (Fig. 2). The fracture wall alteration and the absence of fracture surface mineralization suggest only dissolution of the fracture wall, while the precipitation from the fluid took place somewhere else, possibly being at the origin of the pegmatite and aplite dikes in structurally higher levels of the pluton or of its country rock. In this sense, the weakly altered granite represents the oldest alteration event affecting the studied samples.

A younger fracturing event affecting the studied rock samples is represented by fractures of set 4 . Given the association of the high fracture density and the fault character of the steep fractures, the development of the green facies was preceded by formation of faults belonging to the fracture set 4 . Taking into account the superposition of weathering on the hydrothermal alteration and the pervasive character of both the brittle deformation and the alteration for the yellow granite, the latter was conditioned by formation of the faults of set 3 . This suggests the faults of set 3 are younger than the faults of set 4 .

High fracture density, presence of steep fractures and pervasive alteration are also characteristics of the brown granite in the fracture corridor. From this point of view, even the brown granite can be associated with set 4 faults. However, gently dipping fractures are also present and the dip directions of the fractures at the level of the brown granite are unknown since the borehole images do not capture the uppermost $22 \mathrm{~m}$.

The youngest fracturing event is represented by the exfoliation joints. The age of their formation caused by unloading due to erosion of the overburden can be approximately constrained to late Carboniferous. This is suggested by the onset of deposition of exhumed and eroded crustal material including high grade rocks of the Variscan orogen in the Bohemian Massif (Hartley and Otava, 2001). The extent of the exfoliation joints in the borehole overlaps with the occurrence of the red iron-rich infills characteristic of the pink alteration. Within this extent, the pink alteration is the only one to also appear on its own as demonstrated by the iron-rich material along cracks and grain boundaries in otherwise unaltered primary mineralogy of the fresh granite (Fig. 2). The red infills, however, occur also in the green, the yellow and the brown granite. In the green granite, some of the gently dipping fractures exclusively contain the red infills, while the steeply dipping fractures are filled by the green clay-rich material or by a combination of both materials. These observations suggest that the pink alteration postdates the exfoliation joints and that it is the latest alteration event affecting the studied samples.

\subsection{The void space structure modifications due to fracturing and alteration}

The fracturing and hydrothermal or weathering alteration induced changes in the porosity organization and in mineralogical contents especially for secondary mineral phases.

Two of the studied facies illustrate the porosity network of unaltered granite: the fresh facies corresponds to the initial state of the granite and the fractured facies represents the fracture vicinity without fluid-rock interactions. The low void space in the fresh granite is dominantly distributed in two structures: the illite aggregates in plagioclase grains and the poorly interconnected cracks. Together, they represent the total connected porosity of $0.3 \%$ with the TSD volumetrically centered on $0.2 \mu \mathrm{m}$. Taking into account the sizes of the connected voids as observed under the microscope, we suggest that the smaller throats of the TSD $(0.02-0.2 \mu \mathrm{m})$ represent connections with intergranular spaces inside the illite aggregates, that the larger throats $(0.2-0.4 \mu \mathrm{m})$ correspond to the cracks and that the volumetric proportions related to either of the structures are similar. The link between the throat-size ranges and the structures is also supported by the trends described below for the fractured and the yellow facies characterized by high crack density, on the one hand, and the green facies with sealed cracks and frequent illite aggregates on the other hand.

The effect of cracking unbiased by any alteration emerges from the comparison of the void space of the fresh granite and of the fractured granite, which both feature the primary mineralogy. Our results show that compared to the fresh granite, the fractured granite has a higher porosity with larger throats, higher density, greater thickness and more interconnection of cracks. The stress-induced origin of this porosity corresponds to the observations comparing the unstressed and stressed Westerly granite (Sprunt and Brace, 1974; Tap- 
ponnier and Brace, 1976). This means that the fracturing process increases the volume of void space by increasing the crack density as well as their thickness, the latter evolving from $0.2-0.4$ to $0.2-0.7 \mu \mathrm{m}$. This thickness increase may correspond to the evolution from cracked grain boundaries to cracks (Brace et al., 1972; Kranz, 1979a, b). The presence of an interconnected network of cracks is also supported by the increase in free porosity and is the main cause for higher permeability (Fig. 11c).

Fluid flow alteration processes superpose on the fractured granite and form several facies depending on the volume of fluid and the pressure and temperature conditions.

The weakly altered granite differs from the fractured granite by chlorite replacing biotite but otherwise the void space geometry of both facies is similar. This means that even at obvious alteration of the rock microstructure (biotite-chlorite) the impact on the void space geometry can be negligible. Also, the fracture surface of the weakly altered granite has no specific porosity property as compared to the fracture wall few millimeters from that surface. This is important since for the other altered facies, all the specimens including fracture surface yielded different MIP results as compared to analogous specimens without it.

Chronologically, the green facies developed next within a $\mathrm{N}-\mathrm{S}$ striking subvertical fault zone during relatively hot fluid circulation prior to the weathering phase. In terms of void space geometry, the green granite highlights the impact of pervasive illitization on granite in the high-density fracture zone. Under FL the illite aggregates filling fractures and replacing plagioclase grains feature submicroscopic voids and the MIP yields important porosity for throat sizes on the order of $10^{-2} \mu \mathrm{m}$. This suggests that the majority of the matrix porosity resides in the illite aggregates and it explains the striking contrast between the high fracture density and the low matrix porosity around $1.5 \%$. In association with the lowest MTS of $0.1 \mu \mathrm{m}$, the permeability calculated for the green granite matrix is lower than for the fresh granite. The sealing function of the illite aggregates may not be the dominant factor when open cracks or fractures are present in the rock. As can be seen macroscopically (specimen 9_1, Fig. 3a) and microscopically (Fig. 7d), the fractures or cracks can be filled with the illite aggregates incompletely or can be cutting the illite infills. According to our MIP results this may superpose an additional $0.5 \%-1.5 \%$ of porosity with throat sizes ranging from those typical for the cracks of the fractured granite $(0.2-1 \mu \mathrm{m})$ to those of the thick cracks $\left(10^{0}-\right.$ $10^{1} \mu \mathrm{m}$; cf. Figs. $10 \mathrm{~b}$ and 11a). As a consequence, the permeability can be on the same order of magnitude as for the fractured granite (Fig. 11c) though with a much more complicated porosity structure. During the weathering phase, the pink alteration affected the deeper part of the upper $65 \mathrm{~m}$ profile, while the brown facies concerns the top of the weathering sequence; the intensity of the weathering is higher in the upper part than in the lower one.
The pink alteration materialized by iron-rich precipitates frequently seals the cracks. This is reflected in the MIP results by the lowest incremental porosities in the characteristic range of the cracks $(>0.2 \mu \mathrm{m}$, also compare the curves "fractured" and "pink single fracture" in Fig. 10) and on the bulk values by lower total porosity, lower MTS and lower free porosity as compared to the fractured granite (Fig. 11a, c). The difference between more and less densely fractured pink granite is similar to the difference between the fractured and the fresh granite, respectively: increase in total porosity, higher incremental porosities dominant for larger throats and increase in the maximum throat size.

The effects of fracturing and of the pink alteration are concurrent: while fracturing increases the total porosity, increases the proportion of cracks on the total porosity and increases the threshold size of the connections, the pink alteration acts in the opposite way on all three parameters. While this holds for the rock matrix, the fracture infills induce variation of this principle. The simplest case is the reduction of size of the connections to the void space of the matrix without simultaneous reduction of the void space volume as observed by comparison of the MIP results (Figs. 10b and 11a) of the specimens with and without the most common form of the fracture infill (4_1 and 4_2, respectively, cf. Fig. 3).

The void space of the matrix of the brown granite near a single fracture is characterized by moderate porosity around $1.5 \%$ made of structures with throat sizes distributed over 4 orders of magnitude (Fig. 10). Under FL, this corresponds to the visibility of patchy areas in plagioclase grains partially replaced by porous illite aggregates and to the cracks of variable thickness including remarkably thick cleavage cracks in chlorite and thick intergranular cracks (Fig. 7e). Analogously to the observation on the pink granite, the presence of the iron-rich fracture infill in the brown granite results in reduced maximum throat size and a shift of the distribution towards smaller sizes at otherwise similar total porosity (Figs. 10b and 11a). The matrix of the brown granite in the fracture corridor differs by a higher density of the cracks and also by the presence of large lens-shaped or oval cavities including those with millimetric dimensions (Fig. 7f) that are visible even macroscopically within a centimeter from the master fracture plane (Fig. 2). This situation is reflected in the MIP curves as single or multiple peaks for throat sizes on the orders of $10^{0}-10^{1} \mu \mathrm{m}$.

The yellow granite can be regarded as the result of superposition of both hydrothermal and weathering alteration. First it suffered the tectonic and hydrothermal strain and later it was affected by weathering in a fluid flow zone, which was efficient proportionally to the fault zone thickness. As a consequence, it is the most fractured and the most altered granite and the associated fault gouge has the highest total porosity among the matrix-representative specimens (Fig. 11a). Its unique void space structures related to alteration are the illite aggregates in pseudomorphs after biotite. The replacement is frequently complete and results in a microstructure charac- 
terized by a network of porous areas in thin sections having outlines and residual traces of cleavage of the replaced minerals (Fig. 5g). While this microstructure corresponds to the matrix porosity of $2.5 \%$, the specimen containing the fracture infill yielded a total porosity of $3.8 \%$ suggesting the infill contains approximately one-third of the rock total porosity. Moreover, the high incremental porosities for throat sizes around $1 \mu \mathrm{m}$ (Fig. 10b) and the high value of free porosity $(0.9 \%$, Fig. 11c) suggest an important contribution of cracks to the infill porosity. The porosity difference between the fault gouge and the fracture corridor rocks shows a similar effect of fracturing as described above for the less and more fractured samples of the unaltered and the pink facies: increase in total porosity, higher incremental porosities for larger throats and increase in the maximum throat size. Remarkably, the fault gouge features less porosity accessible by the smallest measured throats $\left(10^{-2}-10^{-1} \mu \mathrm{m}\right)$, which can be due to the fracturing or wear process disrupting the illite aggregates.

\subsection{Coupling between the microstructural, chemical, optical, porosity and permeability properties}

Microstructural evolution during the different kinds of strain affecting the granite involves porosity modifications and induces permeability variations. The objective of this paper is to define these links and to develop a chart linking these properties. Drilling of borehole is rarely realized with coring and only cuttings are available to give information about the rock characteristics. In such a situation, measurements of the transfer properties are difficult. That is why links between rock facies, using simple descriptive chemical and optical properties, and petrophysical properties, mainly porosity and permeability, are constrained in this paper; refer to Figs. 2, 5, 11 and 12 throughout this section.

We suggest that the different alteration facies can be defined based on the biotite alteration, which is easily discernable by the optical properties and by the chemical composition differences expressed by a combination of the $\mathrm{Si} / \mathrm{Al}$ ratio and the sum of the interlayer cations. The only exception is the pink facies where the primary mineralogy is not modified, however, macroscopic and microscopic differences with respect to the other facies are obvious due to saturation by the red iron-rich infills (also cf. Fig. 9).

The fresh granite void space consists of infrequent grain boundary cracks implying very low porosity and permeability. Such a material can be identified by the low $\mathrm{Si} / \mathrm{Al}$ ratio and standard optical properties of biotite.

The weakly altered fractured granite can be expected near barren fractures and identified by replacement of biotite by chlorite 1 with a slightly higher $\mathrm{Si} / \mathrm{Al}$ ratio and distinct optical properties. Porosity can be expected to be several times higher and permeability up to 1 order of magnitude higher as compared to the fresh granite.
The green granite is characterized by chlorite 2 with similar $\mathrm{Si} / \mathrm{Al}$ ratio and sum of interlayer cations as the chlorite 1 in the weakly altered granite. However, under the microscope, the pervasive illitization helps to distinguish it from the latter. Low to moderate porosity can be expected, but due to the very low pore throat size, the permeability may be similar or lower as compared to the fresh granite.

The pink granite remarked macroscopically and microscopically by the iron-rich infills is among the least permeable facies owing to the low porosity and very low throat size. However, special attention should be paid to the character of the fracture infills, which can substantially increase both porosity and the throat size and consequently may be associated with high permeability (cf. Fig. 3).

The brown granite representing intensive weathering alteration can be identified by chlorite 3 with $\mathrm{Si} / \mathrm{Al}$ ratio around 1.3 and sum of the interlayer cations around 0.2. Due to the moderate porosity of the matrix, which includes voids with large throats, the permeability can be expected to be at least two orders of magnitude higher than for the fresh granite. In the most fractured and altered form, very high porosity between $6 \%$ and $7 \%$ with large throats can induce permeability on the order of $10^{-15} \mathrm{~m}^{2}$.

The yellow granite representing the superposition of pervasive cracking and both hydrothermal and weathering alteration can be identified by chlorite 4 with the highest $\mathrm{Si} / \mathrm{Al}$ ratio of 1.7 and the sum of the interlayer cations around 0.4 . The fault gouge in the yellow granite facies features high porosity of $4.5 \%$ and a characteristic throat size of $1 \mu \mathrm{m}$, which correspond to high permeability of up to $10^{-16} \mathrm{~m}^{2}$.

Indeed, the chemical signature (Fig. 6) could be used to estimate the porosity and the permeability (Fig. 11) from analyses of chlorite sampled in cuttings of destructive drilling. The appropriate charts may be like the one in Fig. 12 and may be applied for mineralogically and chemically analogous granitic material altered in similar conditions as well as for weathering and hydrothermal processes. In a broader geological sense, we suggest this is plausible for granites in a similar setting as the studied Lipnice granite: two-mica Sgranite genetically linked and tectonically intimately accompanied with metapelitic migmatites affected by hydrothermal alteration (under green schist conditions) and weathering.

\subsection{General implications for fracture-related microporosity structure}

When generalized, some of the observations contribute to frequently discussed topics concerning the relation between macroscopic fractures or fault zones and the structure of microporosity in their vicinity.

It appears from the measured throat size distributions that fracturing not only enlarges the threshold size of connections through crack formation but also eliminates structures with small threshold size through destruction of the associated small-throat structures (the illite aggregates in our case). 


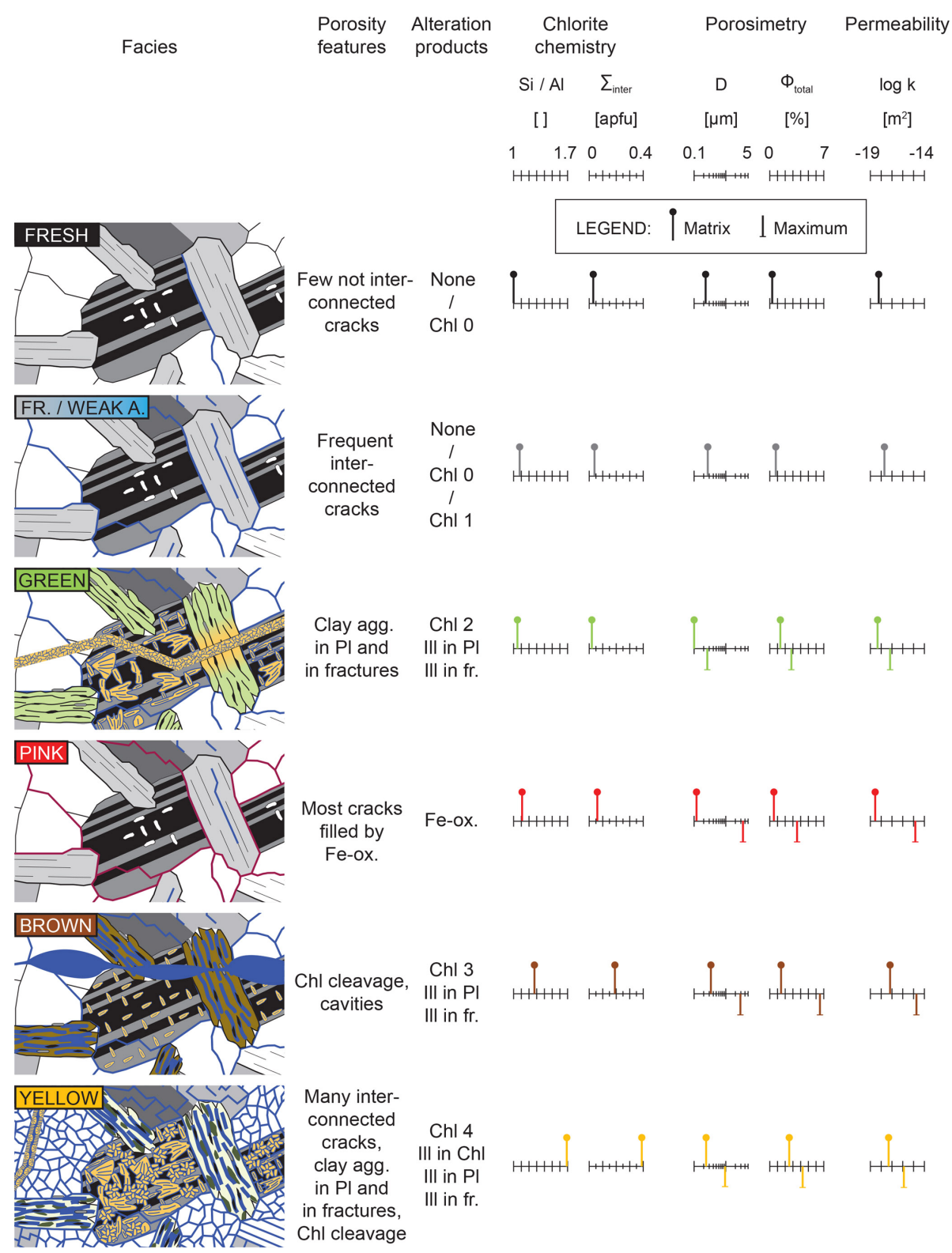

Figure 12. Synthesis of microstructural, chemical and porosimetric observations. Chl: chlorite, Pl: plagioclase, Ill: illite, Fe-ox.: iron oxides, fr.: fractured, a.: altered, agg.: aggregates, $\sum_{\text {inter}}$ : sum of interlayer cations (K, Na, Ca), D: volumetric median throat size, $\Phi$ : porosity, k: permeability and apfu: atoms per formula unit.

Admitting the methodological limits of this observation, this suggests there is a critical minimum thickness for a newly formed crack. Based on our results, this critical value is on the order of $10^{-1} \mu \mathrm{m}$.

The comparison of porosity parameters of specimens representing the rock matrix near a single fracture vs. within a fracture corridor shows an increase in both porosity and throat size with fracture density. Conceptually, this corresponds to the transition from localized conduit to distributed conduit (Caine et al., 1996).
Although the pink alteration reduces both porosity and throat size in the vicinity (several centimeters in our case) of fractures, within several centimeters beyond the alteration halo these porosity parameters are similar as in the vicinity of a barren fracture with a weakly altered fracture wall. This corresponds to the situation of combined conduitbarrier (Caine et al., 1996) implying a sealing structure along the fracture plane that isolates permeable structures on either side.

With the limits given by the number and selection of our samples, it appears that all the fractured granite is altered at 
least in a spatially restrained alteration halo. This means not only that the fractures enable fluid circulation but also that all of them explicitly were subject to it. Extrapolating even further, this implies interconnection within the fracture system of the pluton. Expressed less generally, it implies that every fracture is connected to at least one different fracture. Since some fractures show a single type of alteration (weakly altered and pink granite) and other fractures show a combination of the alteration facies, the connection between different fractures or between different fracture sets is a challenging topic.

The matrix-representative specimens feature lower or similar total porosity as compared to the specimens with fracture infills from the respective facies. With one exception, this means that the fracture infills are more porous than the matrix. This holds even though the iron-rich and the illiterich infills imply a reduction in the size of the connections towards the matrix as described above. The only exception where we cannot prove or disapprove it is the thin infill layer of the specimen 4_1 (pink facies). However, it is possible that its low thickness induced too low a difference in the infillrelated porosity regarding the MIP method sensitivity.

\section{Conclusions}

Fracturing increases porosity, threshold size and the proportion of free porosity of the damage zone, which all increase permeability. The pink alteration characterized by Fe-rich crack infills simply acts in the opposite way.

As shown in the example of the weakly altered granite, a mineralogically altered fracture wall may bear the same porosity properties as an unaltered fracture wall. As shown in the same example, the fracture wall alteration may happen without modification of the fracture surface porosity properties.

Although all fracture walls are altered, they may not be altered in the whole volume of the damage zone. In other words the alteration halo can reach only a limited volume of the damage zone, while the wall rock beyond that halo may be cracked but not altered. Supposing the alteration is due to a fluid-rock interaction enabled by the crack network, a question arises why there is no alteration in the whole network and what controls the position of the front between the altered and the unaltered damage zone.

Fe-rich crack infills and illite aggregates have been identified as sealing features owing to throat-size reduction. However, while the illite aggregates are carriers of porosity, the Fe-rich crack infills appear to be non-porous.

Several porosity structures that can be expected to exist in various types of rock were attributed to a typical throat size. The illite aggregates are characterized by throat sizes on the order of $10^{-2} \mu \mathrm{m}$. Incipient penny-shaped cracks seem to have a critical minimum thickness on the order of $10^{-1} \mu \mathrm{m}$. The thickness of cracks in intensively cracked fault rock, which are still of a rather penny-shaped geometry is typically $1 \mu \mathrm{m}$. Larger throats $\left(10^{0}-10^{1} \mu \mathrm{m}\right)$ characterize voids with a probably crack-related origin; however, with more complicated geometry of, for example, oval-shaped cavities and tortuous or irregularly filled fractures.

Many challenges arise for further work that can be helped by this study. Interpretation of available structural data on the pluton and its country rock may depict a rather constrained model of the granite deformation history. The petrologic parameters of the fracture wall and of the fracture infills may be investigated in greater detail to shed more light on the pressure-temperature-time evolution of the alteration facies with respect to the fracture system. A future study focusing on the structural and physical property anisotropy may boost the value of our results expressed in scalar quantities. Knowledge about the rock transport properties can be improved by results from alternative porosimetry methods such as nuclear magnetic resonance.

Data availability. The dataset is available at https://doi.pangaea.de/ 10.1594/PANGAEA.898002 (Staněk and Géraud, 2019).

Author contributions. MS designed and carried out the experiments, treated and visualized the data regarding all the analytical methods, prepared the manuscript including the text and the figures and for the most part led the manuscript submission, peer-review and publication process.

YG contributed by mentorship in all aspects and especially contributed by providing the mercury intrusion porosimetry lab and material, by formulation of the overarching research goals and aims, and by review and comments on the manuscript.

Both co-authors contributed to the initial research funding acquisition via common $\mathrm{PhD}$ and post-doc French Government fellowships; YG provided funding for the paper publication costs.

Competing interests. The authors declare that they have no conflict of interest.

Acknowledgements. The constructive comments of Sina Marti and of an anonymous referee were very helpful for improving the quality of the paper during the review process. The Czech Radioactive Waste Repository Authority (RAWRA/SÚRAO) is acknowledged for allowing us to sample the MEL-5 borehole core. Stanislav Ulrich and Marc Diraison are thanked for help during the selection of the samples and for consultation of the research strategy. Ondrej Lexa and Karel Schulmann are thanked for sharing their experience with structural features of the Melechov pluton. Olivier Rouer is thanked for friendly and professional feedback during the microprobe analyses.

Edited by: Florian Fusseis

Reviewed by: Sina Marti and one anonymous referee 


\section{References}

Banfield, J. F. and Eggleton, R. A.: Analytical Transmission Electron Microscope Studies of Plagioclase, Muscovite, and KFeldspar Weathering, Clays Clay Miner., 38, 77-89, 1990.

Bankwitz, P., Bankwitz, E., Thomas, R., Wemmer, K., and Kämpf, H.: Age and depth evidence for pre-exhumation joints in granite plutons: fracturing during the early cooling stage of felsic rock, Geol. Soc. Lond. Spec. Publ., 231, 25-47, https://doi.org/10.1144/GSL.SP.2004.231.01.03, 2004.

Bense, V. F., Gleeson, T., Loveless, S. E., Bour, O., and Scibek, J.: Fault zone hydrogeology, Earth-Sci. Rev., 127, 171-192, https://doi.org/10.1016/j.earscirev.2013.09.008, 2013.

Benson, P. M., Meredith, P. G., and Schubnel, A.: Role of void space geometry in permeability evolution in crustal rocks at elevated pressure, J. Geophys. Res.-Solid Earth, 111, B12203, https://doi.org/10.1029/2006JB004309, 2006.

Bernabé, Y., Mok, U., and Evans, B.: Permeability-porosity relationships in rocks subjected to various evolution processes, Pure Appl. Geophys., 160, 937-960, 2003.

Bertrand, L., Jusseaume, J., Géraud, Y., Diraison, M., Damy, P.-C., Navelot, V., and Haffen, S.: Structural heritage, reactivation and distribution of fault and fracture network in a rifting context: Case study of the western shoulder of the Upper Rhine Graben, J. Struct. Geol., 108, 243-255, https://doi.org/10.1016/j.jsg.2017.09.006, 2018.

Boyce, A., Fulignati, P., and Sbrana, A.: Deep hydrothermal circulation in a granite intrusion beneath Larderello geothermal area (Italy): constraints from mineralogy, fluid inclusions and stable isotopes, J. Volcanol. Geotherm. Res., 126, 243-262, https://doi.org/10.1016/S0377-0273(03)00150-1, 2003.

Brace, W. F., Walsh, J. B., and Frangos, W. T.: Permeability of granite under high pressure, J. Geophys. Res., 73, 2225-2236, https://doi.org/10.1029/JB073i006p02225, 1968.

Brace, W. F., Silver, E., Hadley, K., and Goetze, C.: Cracks and Pores: A Closer Look, Science, 178, 162-164, https://doi.org/10.1126/science.178.4057.162, 1972.

Breiter, K. and Sulovský, P.: Geochronology of the Melechov granite massif, Geosci. Res. Rep. 2004, 38, 16-19, 2005.

Buiting, J. J. M. and Clerke, E. A.: Permeability from porosimetry measurements: Derivation for a tortuous and fractal tubular bundle, J. Pet. Sci. Eng., 108, 267-278, https://doi.org/10.1016/j.petrol.2013.04.016, 2013.

Caine, J. S., Evans, J. P., and Forster, C. B.: Fault zone architecture and permeability structure, Geology, 24, 1025, https://doi.org/10.1130/00917613(1996)024<1025:FZAAPS>2.3.CO;2, 1996.

David, C., Wong, T.-F., Zhu, W., and Zhang, J.: Laboratory measurement of compaction-induced permeability change in porous rocks: Implications for the generation and maintenance of pore pressure excess in the crust, Pure Appl. Geophys., 143, 425-456, https://doi.org/10.1007/BF00874337, 1994.

Evans, J. P., Forster, C. B., and Goddard, J. V.: Permeability of fault-related rocks, and implications for hydraulic structure of fault zones, J. Struct. Geol., 19, 1393-1404, https://doi.org/10.1016/S0191-8141(97)00057-6, 1997.

Faulkner, D. R., Jackson, C. A. L., Lunn, R. J., Schlische, R. W., Shipton, Z. K., Wibberley, C. A. J., and Withjack, M. O.: A review of recent developments concerning the structure, mechan- ics and fluid flow properties of fault zones, J. Struct. Geol., 32, 1557-1575, https://doi.org/10.1016/j.jsg.2010.06.009, 2010.

Faulkner, D. R., Mitchell, T. M., Jensen, E., and Cembrano, J.: Scaling of fault damage zones with displacement and the implications for fault growth processes, J. Geophys. Res., 116, B05403, https://doi.org/10.1029/2010JB007788, 2011.

Ferry, J. M.: Reaction mechanisms, physical conditions, and mass transfer during hydrothermal alteration of mica and feldspar in granitic rocks from south-central Maine, USA, Contrib. Mineral. Petrol., 68, 125-139, https://doi.org/10.1007/BF00371895, 1979.

Franke, W.: The mid-European segment of the Variscides: tectonostratigraphic units, terrane boundaries and plate tectonic evolution, Geological Society, London, Special Publications, 179, 3561, https://doi.org/10.1144/GSL.SP.2000.179.01.05, 2000.

$\mathrm{Gao}, \mathrm{Z}$. and $\mathrm{Hu}, \mathrm{Q} .:$ Estimating permeability using median porethroat radius obtained from mercury intrusion porosimetry, J. Geophys. Eng., 10, 025014, https://doi.org/10.1088/17422132/10/2/025014, 2013.

Géraud, Y.: Variations of connected porosity and inferred permeability in a thermally cracked granite, Geophys. Res. Lett., 21, 979-982, https://doi.org/10.1029/94GL00642, 1994.

Géraud, Y., Caron, J., and Faure, P.: Porosity network of a ductile shear zone, J. Struct. Geol., 17, 1757-1769, https://doi.org/10.1016/0191-8141(95)00067-N, 1995.

Géraud, Y., Diraison, M., and Orellana, N.: Fault zone geometry of a mature active normal fault: A potential high permeability channel (Pirgaki fault, Corinth rift, Greece), Tectonophysics, 426, 61-76, https://doi.org/10.1016/j.tecto.2006.02.023, 2006.

Géraud, Y., Rosener, M., Surma, F., Place, J., Le Garzic, É., and Diraison, M.: Physical properties of fault zones within a granite body: Example of the Soultz-sous-Forêts geothermal site, Comptes Rendus Geosci., 342, 566-574, https://doi.org/10.1016/j.crte.2010.02.002, 2010.

Gerdes, A., Friedl, G., Parrish, R., and Finger, F.: High-resolution geochronology of Variscan granite emplacement - the South Bohemian Batholith, Journal of the Czech Geological Society, 48, 53-54, 2003.

Gutmanis, J.: Basement Reservoirs - A Review of their Geological and Production Characteristics, International Petroleum Technology Conference, 2009.

Harlov, D. E., Procházka, V., Förster, H.-J., and Matějka, D.: Origin of monazite-xenotime-zircon-fluorapatite assemblages in the peraluminous Melechov granite massif, Czech Republic, Mineral. Petrol., 94, 9-26, https://doi.org/10.1007/s00710-008-0003$8,2008$.

Hartley, A. J. and Otava, J.: Sediment provenance and dispersal in a deep marine foreland basin: the Lower Carboniferous Culm Basin, Czech Republic, J. Geol. Soc., 158, 137-150, https://doi.org/10.1144/jgs.158.1.137, 2001.

Hey, M. H.: A New Review of the Chlorites, Mineral. Mag., 30, 277-292, https://doi.org/10.1180/minmag.1954.030.224.01, 1954.

Hooper, A. J.: 5 - Crystalline geological repository systems: characterisation, site surveying and construction technologies and techniques, in: Geological Repository Systems for Safe Disposal of Spent Nuclear Fuels and Radioactive Waste, edited by: Ahn, J. and Apted, M. J., 121-152, Woodhead Publishing, 2010. 
Jamtveit, B., Malthesorenssen, A., and Kostenko, O.: Reaction enhanced permeability during retrogressive metamorphism, Earth Planet. Sci. Lett., 267, 620-627, https://doi.org/10.1016/j.epsl.2007.12.016, 2008.

Jamtveit, B., Putnis, C. V., and Malthe-Sørenssen, A.: Reaction induced fracturing during replacement processes, Contrib. Mineral. Petrol., 157, 127-133, https://doi.org/10.1007/s00410-0080324-y, 2009.

Jamtveit, B., Kobchenko, M., Austrheim, H., MaltheSørenssen, A., Røyne, A., and Svensen, H.: Porosity evolution and crystallization-driven fragmentation during weathering of andesite, J. Geophys. Res., 116, B12204, https://doi.org/10.1029/2011JB008649, 2011.

Katsube, T. J. and Kamineni, D. C.: Effect of alteration on pore structure of crystalline rocks; core samples from Atikokan, Ontario, Can. Mineral., 21, 637-646, 1983.

Katz, A. J. and Thompson, A. H.: Quantitative prediction of permeability in porous rock, Phys. Rev. B, 34, 8179-8181, https://doi.org/10.1103/PhysRevB.34.8179, 1986.

Katz, A. J. and Thompson, A. H.: Prediction of rock electrical conductivity from mercury injection measurements, J. Geophys. Res., 92, 599, https://doi.org/10.1029/JB092iB01p00599, 1987.

Kranz, R. L.: Crack growth and development during creep of Barre granite, Int. J. Rock Mech. Min. Sci. Geomech. Abstr., 16, 23 35, https://doi.org/10.1016/0148-9062(79)90772-1, 1979a.

Kranz, R. L.: Crack-crack and crack-pore interactions in stressed granite, Int. J. Rock Mech. Min. Sci. Geomech. Abstr., 16, 3747, https://doi.org/10.1016/0148-9062(79)90773-3, 1979b.

Kranz, R. L.: Microcracks in rocks: A review, Tectonophysics, 100, 449-480, https://doi.org/10.1016/0040-1951(83)90198-1, 1983.

Lachassagne, P., Wyns, R., and Dewandel, B.: The fracture permeability of Hard Rock Aquifers is due neither to tectonics, nor to unloading, but to weathering processes: Weathering and permeability of Hard Rock Aquifers, Terra Nova, 23, 145-161, https://doi.org/10.1111/j.1365-3121.2011.00998.x, 2011.

Lenormand, R., Zarcone, C., and Sarr, A.: Mechanisms of the displacement of one fluid by another in a network of capillary ducts, J. Fluid Mech., 135, 337, https://doi.org/10.1017/S0022112083003110, 1983.

Lexa, O. and Schulmann, K.: Provedení geologických a dalších prací na testovací lokalitě Melechovský masiv - 2. etapa. Vyhodnocení povrchových křehkých struktur a puklinové sítě na testovací lokalitě Melechovský masiv - souborná zpráva za období 2004-2006, Czech Geological Survey, 2006.

Long, J. C. S. and Witherspoon, P. A.: The relationship of the degree of interconnection to permeability in fracture networks, J. Geophys. Res., 90, 3087, https://doi.org/10.1029/JB090iB04p03087, 1985.

Machek, M.: Relation of pore space geometry, permeability and microstructure in low-porosity rocks, $\mathrm{PhD}$ Thesis, Charles University in Prague, Prague, 2011.

Matějka, D. and Janoušek, V.: Whole-rock geochemistry and petrogenesis of granites from the northern part of the Moldanubian Batholith (Czech Republic), Acta Univ. Carol. Geol., 42, 73-79, 1998.

Mazurier, A., Sardini, P., Rossi, A. M., Graham, R. C., Hellmuth, K.-H., Parneix, J.-C., Siitari-Kauppi, M., Voutilainen, M., and Caner, L.: Development of a fracture network in crystalline rocks during weathering: Study of Bishop Creek chronose- quence using X-ray computed tomography and 14 C-PMMA impregnation method, Geol. Soc. Am. Bull., 128, 1423-1438, https://doi.org/10.1130/B31336.1, 2016.

Mitchell, T. M. and Faulkner, D. R.: The nature and origin of off-fault damage surrounding strike-slip fault zones with a wide range of displacements: A field study from the Atacama fault system, northern Chile, J. Struct. Geol., 31, 802-816, https://doi.org/10.1016/j.jsg.2009.05.002, 2009.

Moeck, I. S.: Catalog of geothermal play types based on geologic controls, Renew, Sustain. Energy Rev., 37, 867-882, https://doi.org/10.1016/j.rser.2014.05.032, 2014.

Nishimoto, S. and Yoshida, H.: Hydrothermal alteration of deep fractured granite: Effects of dissolution and precipitation, Lithos, 115, 153-162, https://doi.org/10.1016/j.lithos.2009.11.015, 2010.

Nooruddin, H. A., Hossain, M. E., Al-Yousef, H., and Okasha, T.: Comparison of permeability models using mercury injection capillary pressure data on carbonate rock samples, J. Pet. Sci. Eng., 121, 9-22, https://doi.org/10.1016/j.petrol.2014.06.032, 2014.

Procházka, V. and Matějka, D.: Rock-forming accessory minerals in the granites of the Melechov Massif (Moldanubian Batholith, Bohemian Massif), Acta Univ. Carol. Geol., 48, 71-79, 2004.

Rempe, N. T.: Permanent underground repositories for radioactive waste, Prog. Nucl. Energy, 49, 365-374, https://doi.org/10.1016/j.pnucene.2007.04.002, 2007.

Rosener, M. and Géraud, Y.: Using physical properties to understand the porosity network geometry evolution in gradually altered granites in damage zones, Geol. Soc. Lond. Spec. Publ., 284, 175-184, https://doi.org/10.1144/SP284.12, 2007.

Schild, M., Siegesmund, S., Vollbrecht, A., and Mazurek, M.: Characterization of granite matrix porosity and pore-space geometry by in situ and laboratory methods, Geophys. J. Int., 146, 111125, https://doi.org/10.1046/j.0956-540x.2001.01427.x, 2001.

Scholz, C. H., Dawers, N. H., Yu, J.-Z., Anders, M. H., and Cowie, P. A.: Fault growth and fault scaling laws: Preliminary results, J. Geophys. Res.-Solid Earth, 98, 21951-21961, https://doi.org/10.1029/93JB01008, 1993.

Schulmann, K., Venera, Z., Konopásek, J., and Lexa, O.: Strukturní a petrologický výzkum melechovského masivu, zpráva za rok 1997, Faculty of Science of the Charles University in Prague, Prague, 1998.

Schulmann, K., Lexa, O., Štípská, P., Racek, M., Tajčmanová, L., Konopásek, J., Edel, J.-B., Peschler, A., and Lehmann, J.: Vertical extrusion and horizontal channel flow of orogenic lower crust: key exhumation mechanisms in large hot orogens?, J. Metamorph. Geol., 26, 273-297, https://doi.org/10.1111/j.15251314.2007.00755.x, 2008.

Sprunt, E. S. and Brace, W. F.: Direct observation of microcavities in crystalline rocks, Int. J. Rock Mech. Min. Sci. Geomech. Abstr., 11, 139-150, https://doi.org/10.1016/0148-9062(74)928745, 1974.

Šrámek, J., Sedlák, J., and Obr, J.: Melechovský masív, vizualizace tíhových dat a kvantitativní tíhový řez, Gravimetrické a petrofyzikální práce na lokalitě Dolní Město v etapě 1995-1996, Geofyzika, a.s., Brno, Brno, 1996.

Staněk, M.: Structural and Petrophysical Characterisation of Granite Intended for Radioactive Waste Storage, PhD Thesis, Charles University in Prague, University of Strasbourg, Prague, Strasbourg, 2013. 
Staněk, M. and Géraud, Y.: Chemical compositions and structural formulas of phyllosilicates and throat size distributions of granite samples from the MEL-5 borehole, PANGAEA, available at: https://doi.pangaea.de/10.1594/PANGAEA.898002, 2019

Staněk, M., Géraud, Y., Lexa, O., Špaček, P., Ulrich, S., and Diraison, M.: Elastic anisotropy and pore space geometry of schlieren granite: direct 3-D measurements at high confining pressure combined with microfabric analysis, Geophys. J. Int., 194, 383394, https://doi.org/10.1093/gji/ggt053, 2013.

Tapponnier, P. and Brace, W.: Development of stress-induced microcracks in Westerly Granite, Int. J. Rock Mech. Min. Sci. Geomech. Abstr., 13, 103-112, https://doi.org/10.1016/01489062(76)91937-9, 1976.

Trice, R.: Basement exploration, West of Shetlands: progress in opening a new play on the UKCS, Geol. Soc. Lond. Spec. Publ., 397, 81-105, https://doi.org/10.1144/SP397.3, 2014.

Trubač, J., Žák, J., Chlupáčová, M., and Janoušek, V.: Magnetic fabric and modeled strain distribution in the head of a nested granite diapir, the Melechov pluton, Bohemian Massif, J. Struct. Geol., 66, 271-283, https://doi.org/10.1016/j.jsg.2014.05.015, 2014.

Vermilye, J. M. and Scholz, C. H.: Fault propagation and segmentation: insight from the microstructural examination of a small fault, J. Struct. Geol., 21, 1623-1636, https://doi.org/10.1016/S0191-8141(99)00093-0, 1999.

Verner, K., Žák, J., Šrámek, J., Paclíková, J., Zavřelová, A., Machek, M., Finger, F., and Johnson, K.: Formation of elongated granite-migmatite domes as isostatic accommodation structures in collisional orogens, J. Geodyn., 73, 100-117, https://doi.org/10.1016/j.jog.2013.10.002, 2014.

Walter, B., Géraud, Y., Bartier, D., Kluska, J.-M., Diraison, M., Morlot, C., and Raisson, F.: Petrophysical and mineralogical evolution of weathered crystalline basement in western Uganda: Implications for fluid transfer and storage, AAPG Bull., 102, 10351065, https://doi.org/10.1306/0810171610917171, 2018.

Wardlaw, N. C. and McKellar, M.: Mercury porosimetry and the interpretation of pore geometry in sedimentary rocks and artificial models, Powder Technol., 29, 127-143, https://doi.org/10.1016/0032-5910(81)85011-5, 1981.

Wardlaw, N. C., Li, Y., and Forbes, D.: Pore-throat size correlation from capillary pressure curves, Transp. Porous Media, 2, 597614, https://doi.org/10.1007/BF00192157, 1987.

Washburn, E. W.: Note on a Method of Determining the Distribution of Pore Sizes in a Porous Material, P. Natl. Acad. Sci. USA, 7, 115-116, 1921.
Wilson, J., Chester, J., and Chester, F.: Microfracture analysis of fault growth and wear processes, Punchbowl Fault, San Andreas system, California, J. Struct. Geol., 25, 1855-1873, https://doi.org/10.1016/S0191-8141(03)00036-1, 2003.

Wyns, R., Baltassat, J.-M., Lachassagne, P., Legchenko, A., Vairon, J., and Mathieu, F.: Application of proton magnetic resonance soundings to groundwater reserve mapping in weathered basement rocks (Brittany, France), Bull. Soc. Geol. Fr., 175, 21-34, https://doi.org/10.2113/175.1.21, 2004.

Wyns, R., Dewandel, B., and Lachassagne, P.: Origin of fracturation in hard-rock aquifers: what are the factors that control the properties of the fissured horizon?, https://doi.org/10.13140/rg.2.1.3699.3124, 2015.

Yoshida, H., Metcalfe, R., Seida, Y., Takahashi, H., and Kikuchi, T.: Retardation capacity of altered granitic rock distributed along fractured and faulted zones in the orogenic belt of Japan, Eng. Geol., 106, 116-122, https://doi.org/10.1016/j.enggeo.2009.03.008, 2009.

Yu, L. and Wardlaw, N. C.: Mechanisms of nonwetting phase trapping during imbibition at slow rates, J. Colloid Interface Sci., 109, 473-486, https://doi.org/10.1016/0021-9797(86)90325-5, 1986a.

Yu, L. and Wardlaw, N. C.: The influence of wettability and critical pore-throat size ratio on snap-off, J. Colloid Interface Sci., 109, 461-472, https://doi.org/10.1016/0021-9797(86)90324-3, 1986b.

Žák, J., Verner, K., Finger, F., Faryad, S. W., Chlupáčová, M., and Veselovský, F.: The generation of voluminous S-type granites in the Moldanubian unit, Bohemian Massif, by rapid isothermal exhumation of the metapelitic middle crust, Lithos, 121, 25-40, https://doi.org/10.1016/j.lithos.2010.10.002, 2011.

Žák, J., Verner, K., Janoušek, V., Holub, F. V., Kachlík, V., Finger, F., Hajná, J., Tomek, F., Vondrovic, L., and Trubač, J.: A plate-kinematic model for the assembly of the Bohemian Massif constrained by structural relationships around granitoid plutons, Geol. Soc. Lond. Spec. Publ., 405, 169-196, https://doi.org/10.1144/SP405.9, 2014.

Zang, A., Wagner, F. C., Stanchits, S., Janssen, C., and Dresen, G.: Fracture process zone in granite, J. Geophys. Res.-Solid Earth, 105, 23651-23661, https://doi.org/10.1029/2000JB900239, 2000.

Zoback, M. D. and Byerlee, J. D.: The effect of microcrack dilatancy on the permeability of westerly granite, J. Geophys. Res., 80, 752-755, https://doi.org/10.1029/JB080i005p00752, 1975. 